\title{
Sedimentological and ichnological implications of rapid Holocene flooding of a gently sloping mud-dominated incised valley - an example from the Red River (Gulf of Tonkin)
}

\author{
Andreas Wetzel ${ }^{1}$, Agata Szczygielski ${ }^{2}$, Daniel Unverricht ${ }^{2}$ and Karl Stattegger ${ }^{2}$ \\ ${ }^{1}$ Geologisch-Paläontologisches Institut, Universität Basel, Bernoullistrasse 32, CH-4056 \\ Basel, Switzerland (E-mail: andreas.wetzel@unibas.ch) \\ ${ }^{2}$ Institut für Geowissenschaften, Christian-Albrechts Universität, Otto-Hahn-Platz 1, \\ D-24118 Kiel, Germany
}

Published 2017 in: Sedimentology, 64: 1173-1202

doi: $10.1111 /$ sed.12357

\begin{abstract}
The Gulf of Tonkin coastline migrated at an average rate of ca $60 \mathrm{~m} /$ year landward during Holocene sea-level rise (20 to $8 \mathrm{ka}$ ). Due to a combination of rapid coastline migration and undersupply of sand, neither coastal barriers nor tidal sand bars developed at the mouth of the Red River incised valley. Only a 30 to $80 \mathrm{~cm}$ thick sandy interval formed at the base of fullmarine deposits. Thus, the river mouth represented a mud-dominated open funnel-shaped estuary during transgression. At the base of the valley fill, a thin fluvial lag deposit marks a period of lowered sea-level when the river did not reach geomorphic equilibrium and was thus prone to erosion. The onset of base-level rise is documented by non-bioturbated to sparsely bioturbated mud that occasionally contains pyrite indicating short-term seawater incursions. Siderite in overlying deposits points to low-salinity estuarine conditions. The open funnelshaped river mouth favoured upstream incursion of seawater that varied inversely to the seasonal strongly fluctuating discharge: several centimetres to a few tens of centimetres thick intervals showing marine or freshwater dominance alternate, as indicated by bioturbational and physical sedimentary structures, and by the presence of $\mathrm{Fe}$ sulphides or siderite, respectively. Recurrent short-term seawater incursions stressed the burrowing fauna. The degree of bioturbation increases upward corresponding to increasing marine influence. The uppermost estuarine sediments are completely bioturbated. The estuarine deposits aggraded on average rapidly, up to several metres/kyr. Siphonichnidal burrows produced by bivalves, however, document recurrent episodes of enhanced deposition $\left(>0 \_5 \mathrm{~m}\right)$ and pronounced erosion $(<1 \mathrm{~m})$ that are otherwise not recorded. The slope of the incised valley affected the sedimentary facies. In steep valley segments, the marine transgressive surface (equivalent to the onset of full-marine conditions) is accentuated by the Glossifungites ichnofacies, whereas in gently sloped valley segments the marine transgressive surface is gradational and bioturbated. Marine deposits are completely bioturbated.
\end{abstract}

Keywords Estuary, Holocene, incised valley, mud, transgression. 


\section{INTRODUCTION}

The fill of incised valleys represents a detailed archive of the complex sedimentological and stratigraphic development of a coastal region during transgression, while adjacent shelf areas often store an incomplete sedimentary record because of physical reworking and/or sediment starvation (e.g. Mattheus \& Rodriguez, 2011). Sediment infill into an incised-valley system depends on the interplay of various factors, such as valley slope, amount and seasonality of river discharge, fluvial sediment load and type, rate of base-level/sea-level change and tidal range (for a review, see Boyd et al., 2006). Because of the large number of variables and, hence, the strong influence of regional and local factors, it is intriguing to unravel the fill history of an incised valley and to understand the spatial arrangement of sedimentary facies and the geometry of depositional units. In particular, sand-rich deposits in incised valleys represent the target of exploration for oil and gas, or water (e.g. Zaitlin et al., 1994). The study of modern estuaries and incised-valley fill deposits in the rock record led to facies models distinguishing wave-dominated and tide-dominated depositional settings; wave-dominated systems are differentiated into fluvial, estuarine bayhead delta and central basin, barrier system and marine realm (e.g. Dalrymple et al., 1992; Dalrymple, 2006; and references therein), while tide-dominated estuaries comprise marine tidal bars and channels, estuarine mixed-energy and fluvial-dominated domains (e.g. Dalrymple et al., 2012).

Valleys incised into modern shelves preferably are seen as counterparts of ancient systems and often the fill geometry on seismic scales is investigated (e.g. Simms et al., 2006; Alqahtani et al., 2015). Cores were mainly used to calibrate seismic records, while detailed sedimentological studies are less numerous (e.g. Tanabe et al., 2015). Mud-dominated fill of valleys incised in front of large modern rivers carrying a high amount of suspended load has not been studied often (e.g. Zhang et al., 2014; Alqahtani et al., 2015). Similarly, there are only a few studies dealing with incised valleys on gently inclined, wide shelves that experienced rapid coastline migration during transgression (e.g. Hanebuth et al., 2011).

During sea-level rise, the mouth of an incised river normally represents an estuarine system (e.g. Boyd et al., 2006). The maximum upstream extent of seawater, the so-called tidal limit, depends on the gradient and geometry of the channel, river discharge, water density and tidal range and may reach a few to tens of kilometres upstream (e.g. Dalrymple et al., 2012). At the interface between fluvial and marine water, the turbidity maximum forms where the high ionic strength of seawater induces flocculation and deposition of mud (e.g. Portela et al., 2013; Carlin et al., 2015). The depositional regime, however, is influenced by tides beyond the tidal limit due to backwater effects (e.g. Dalrymple et al., 2012). To unravel the complex interactions during the fill of an incised valley, besides physical sedimentary structures, trace fossils have been proven to be useful for facies interpretation because the benthic fauna sensitively reacts to environmental factors such as salinity, turbidity, substrate consistency or deposition, bypass or erosion of sediment (e.g. Pemberton et al., 2001). Besides the composition of the trace-fossil suite, penetration depth and size of burrows and degree of bioturbation provide valuable information (e.g. Pemberton, 1992; MacEachern et al., 2009; Buatois \& Mang_ano, 2011). Often biogenic sedimentary structures are more appropriate indicators of the environmental conditions than body fossils because they are autochthonous (e.g. Schäfer, 1956; Hertweck, 1972). Numerous ichnological studies deal with sandy incised- 
valley fill deposits or sandy intervals of such systems and they definitely provide detailed information about the depositional setting (e.g. Pemberton et al., 1992; Gingras et al., 2012).

The fill of incised valleys in the rock record can be unraveled in more detail when taking into account observations in modern settings, for which the environmental conditions are fairly well-known. For instance, the bathymetry of an incised valley and Holocene sea-level rise are rather well-constrained in contrast to fossil counterparts. In addition, geochemical proxies such as X-ray fluorescence (XRF) core-scan data and early diagenetic precipitates, such as siderite and Fe sulphides, are useful to decipher the depositional conditions (e.g. Curtis, 1987; Rickard \& Luther, 2007; Tjallingii et al., 2010).

The aim of this study was to analyse the latest Pleistocene/Holocene transgressive fill of the valley that was incised by the ancient Red River and its tributaries in the Gulf of Tonkin during the last glacial sea-level lowstand. The Red River carries mainly suspended load, and thus the muddy incised-valley fill represents a not often studied case. These deposits document a dynamic environment experiencing long-term rapid sediment aggradation induced by the post-glacial sea-level rise, but also short-term erosion and omission due to seasonal fluctuations of river run-off and interaction with tides close to the river mouth (e.g. La Croix \& Dashtgard, 2014). Both factors lead to variation in flow velocity, salinity changes and a fluctuating boundary of the tidal limit. Seawater incursion favours the flocculation of river suspended load, which affects water turbidity and substrate consistency. These factors also strongly influence the fauna. This study integrates geochemical proxies (XRF core-scan data and early diagenetic Fe-rich precipitates), data of sea-level rise and ichnology, which provides insight into the previous environmental situation and elucidates the dynamics of the depositional system. In addition, the influence of topographic relief is also evaluated, as the Gulf of Tonkin represents a gently inclined wide shelf area.

\section{STUDY AREA AND GEOLOGICAL SETTING}

The South China Sea is surrounded by the southeast Asian mainland in the north and west and the islands of Borneo, Palawan, Luzon and Taiwan to the south and east (Fig. 1). It includes large shelf regions, in particular the Gulf of Tonkin in the north-west and the Sunda Shelf in the south-west. The entire region of the South China Sea is influenced by the monsoon system (e.g. Tomczak \& Godfrey, 1994). Two different regimes of monsoonal circulation affected the South China Sea during the Quaternary (e.g. Wang et al., 1999; Wang \& Li, 2009). Interglacial times (as today) are characterized by weak north-easterly monsoon and weak seasonality. During May to September, the south-westerly monsoon provides humidity and leads to the wet season in the south-east Asian mainland, while during November to March, the north-westerly monsoon reverses and results in a dry season (Wang et al., 1999; Wang \& $\mathrm{Li}, 2009)$. Glacial times are characterized by strong winter monsoon and weak summer monsoon and low wetness in subtropical China (e.g. Wang et al., 1999; Liu et al., 2007). Therefore, fluvial run-off to the northern part of the South China Sea decreased (Wang et al., 1999). During glacial times, when sea-level was lowered by $>100 \mathrm{~m}$, wide shelf areas were exposed and drained by several rivers (e.g. Voris, 2000). 


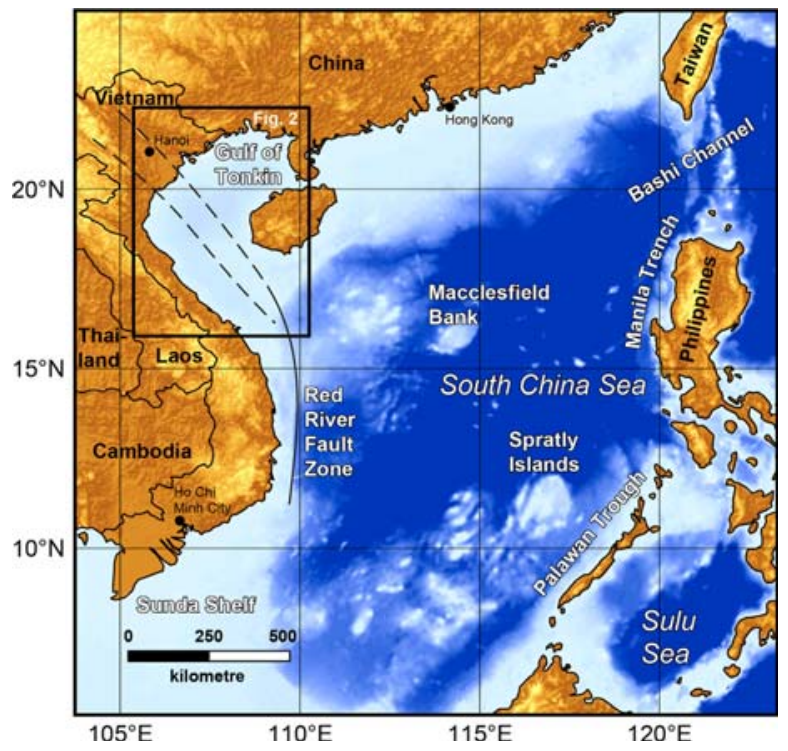

Fig. 1. South China Sea and location of the study area framed by a box shown in more detail in Fig. 2. DEM topographic data were provided by ESRI $^{\circledR}$ Company (Munich, Germany) in combination with GIS software license. Location of the Red River Fault Zone after Fyhn \& Phach (2014).

After the last glacial maximum (LGM), inundation of the exposed shelf areas started between $24 \mathrm{ka}$ and $19.6 \mathrm{ka}$ (Hanebuth et al., 2009) and continued until the mid-Holocene sea-level maximum at ca $6 \mathrm{ka}$ (Stattegger et al., 2013) accentuated by two phases of accelerated sealevel rise at 14.6 to $14.2 \mathrm{ka}$ and 9.0 to $8.2 \mathrm{ka}$ [Melt Water Pulse (MWP) 1A and 1C; Hanebuth et al., 2000; Tjallingii et al., 2014]. Sea-level rise and the concomitant rise of local base level resulted in sediment aggradation in incised valleys and transformed them into estuaries (e.g. Hanebuth \& Stattegger, 2003; Tjallingii et al., 2010). Because of pure geometrical reasons, a pronounced sea-level rise affecting a low-gradient shelf leads to fast inland migration of the coastline as, for instance, described by Hanebuth \& Stattegger (2003). Thin, transgressive shoreface sediments accumulated outside the incised valleys and Holocene marine deposits rest on Pleistocene sediments separated by a rather sharp boundary (e.g. Schimanski \& Stattegger, 2005; Szczuciński et al., 2013) that represents a wave ravinement surface (WRS) sensu Zaitlin et al. (1994).

The Gulf of Tonkin occupies an area of $90^{\prime} 000 \mathrm{~km}^{2}$; it is bordered by the island of Hainan in the east and the Asian mainland to the north and the west (Fig. 2). The Gulf of Tonkin is presently affected by dextral movements along the Red River Fault Zone (Fig. 1; Fyhn \& Phach,2014). The seafloor is covered mainly by siliciclastic sediments; muddy sand is common, but locally sand and gravel have been encountered and occasionally Cenozoic bedrocks crop out (Niino \& Emery, 1961; Ni et al., 2016). The Gulf of Tonkin experiences diurnal tides, with tidal range reaching $4 \mathrm{~m}$ in the north and $2 \mathrm{~m}$ in the south (van Maren, 2007). 


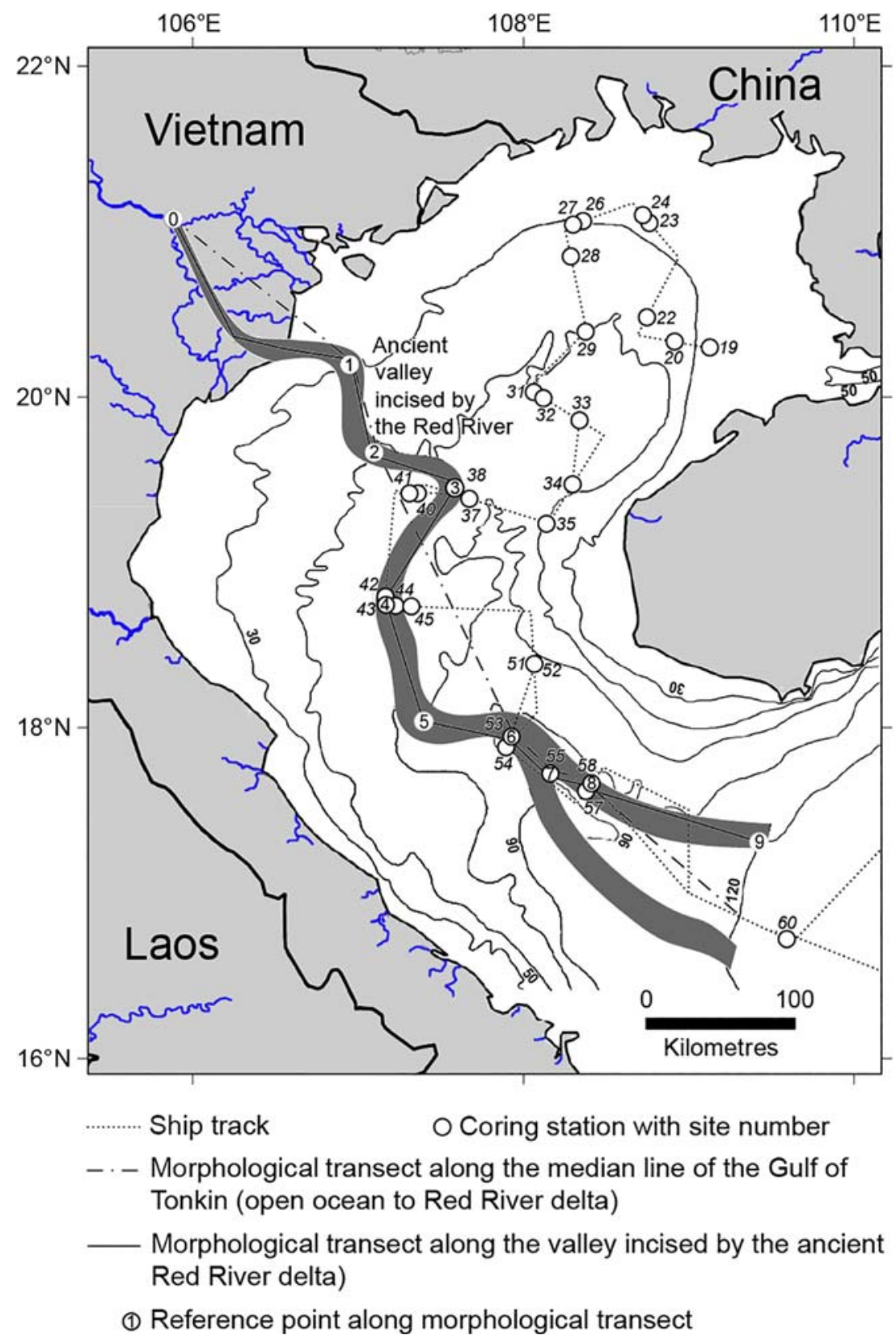

Fig. 2. Gulf of Tonkin with the so far recognized valley that was incised into the exposed coastal plain during Late Pleistocene sea-level lowstand by the ancient Red River. For exact location of sites, see Table 1. Stippled line refers to ship track. Morphological transects (as discussed below, see Fig. 12) along the incised valley and along the median line from open sea to modern Red River delta are marked by solid and broken line, respectively. Encircled numbers represent reference points used for calculation of coastline migration. Reference point (0) today on land refers to coastline position at ca $9 \mathrm{ka}$ as given by Tanabe et al. (2006).

The Red River originates in the mountainous area of Yunnan; it flows for $1150 \mathrm{~km}$ to the Gulf of Tonkin and drains an area of about $168^{\prime} 000 \mathrm{~km}^{2}$ (Haruyama, 1995). The mean annual discharge is around $3810 \mathrm{~m}^{3} / \mathrm{sec}\left(=120 \mathrm{~km}^{3} /\right.$ year), but it fluctuates between $23000 \mathrm{~m}^{3} / \mathrm{sec}$ and $700 \mathrm{~m}^{3} / \mathrm{sec}$ during the wet and dry season, respectively; about three quarters of the discharge occurs during the wet season (July to December; Mathers \& Zalasiewicz, 1999). The river carries about $123 \mathrm{Mt} /$ year suspended load and $10 \mathrm{Mt} /$ year bedload; about $90 \%$ of the annual suspended sediment load is carried during the summer monsoon season (Mathers \& Zalasiewicz, 1999; Borges \& Huh, 2007). Although during glacial times the discharge of the Red River significantly decreased, a well-developed valley was incised into the substrate (Fig. 2; Wiesner et al., 2012). During the middle Holocene, the sediment discharge was about onethird of the present-day value (Tanabe et al., 2006). The modern Red Riverdelta has 
prograded into a drowned valley since ca $8 \mathrm{ka}$, a straight coastline was developed at ca $6 \mathrm{ka}$ and its present lobate shape formed since ca 2 ka (Tanabe et al., 2003, 2006). Today, the northernmost part of the Red River delta is tide-dominated, while the middle and southern part is wave-dominated (south of ca $20.7^{\circ} \mathrm{N}$; e.g. Duc et al., 2007). The Red River traverses an approximately $200 \mathrm{~km}$ wide coastal plain before reaching the modern delta and, during times of lowered sea-level, it formed a piedmont incised valley sensu Zaitlin et al. (1994). The distance between the modern Red River delta and the $120 \mathrm{~m}$ isobaths (shelf margin) is about $500 \mathrm{~km}$.

\section{MATERIAL AND METHODS}

Seismic data and cores were collected during cruise 220 of the German research vessel Sonne in 2012 to the South China Sea (Wiesner et al., 2012). Data from the General Bathymetric Chart of the Oceans (GEBCO) for the Gulf of Tonkin were supplemented by shipboard records. In addition, detailed bathymetric data were provided by Vietnamese authorities. Depth points and contour lines were digitized and combined to georeferenced bathymetric maps. The course of the ancient Red River valley was traced from the recent mouth of the Red River by following the relatively deepest area through the Gulf of Tonkin.

The present study is based on 22 up to $10 \mathrm{~m}$ long $12 \mathrm{~cm}$ diameter gravity cores and 20 up to $40 \mathrm{~cm}$ long $50 \times 50 \mathrm{~cm}^{2}$ box cores taken along seismic transects (Fig. 2; Table 1; Appendix A). The fill sequence was not completely cored in the centre of the main valley, only at its margins. Seismic data were acquired by an Atlas Electronic GmbH Parasound system (Teledyne Reson, Slangerup, Denmark). The thickness of incised-valley fill deposits was calculated from seismic data. For seawater, a sound velocity of $1475 \mathrm{~m} / \mathrm{sec}$ was determined from conductivity, temperature and pressure measurements. Sound velocity of sediments was assumed to be on the order of $1650 \mathrm{~m} / \mathrm{sec}$ as measured in marine sediments having similar composition and porosity (Wetzel et al., 1990).

Descriptions of all cores are based on onboard visual observations, digital camera images and X-ray radiographs, which show sedimentary structures of soft muddy sediments in far more detail than fresh core (e.g. Wetzel, 1981, 2010). For X-ray radiography, about $1 \mathrm{~cm}$ thick sediment slabs were taken from the split core surface directly after opening and sealed to prevent desiccation (Werner, 1967). The slabs were irradiated at the Radiology Section of the Medical Care Center (Prüner Gang) in Kiel (Germany) using a Swissray ddR Multi System (Swissray International Inc., Piscataway, NJ, USA).

High-resolution elemental composition records were measured directly on the split-core surface in a non-destructive way with an Avaatech XRF Core Scanner (Avaatech XRF Technology, Alkmaar, The Netherlands; Tjallingii et al., 2010). After careful cleaning and preparation of the core surface with SPEXCerti Ultralene_foil, the Sonne 220 cores were measured with a sample resolution of $1 \mathrm{~cm}$. This foil avoids both contamination of the instrument sensor and desiccation of the core during the measurements. X-ray fluorescence (XRF) scanner measurements were conducted with a sample time of $30 \mathrm{sec}$ and a generator setting of $10 \mathrm{kV}(30 \mathrm{kV})$, which covers the elements aluminum through to iron (lead). More technical details relating to the XRF core scanner and sample preparation can be found in Richter et al. (2006) and Tjallingii (2007). To eliminate effects of sediment physical properties and sample geometry on the measured data, the ratios or logarithmic ratios of two 
elements were calculated, which can be interpreted as the relative concentrations of two elements (Weltje \& Tjallingii, 2008).

For mineral identification, bulk powdered sediment samples were put into an aluminum tray for XRD analyses using a Siemens D 5000 diffractometer (Siemens, Munich, Germany). Copper K $\alpha 1$ radiation was used measuring $0.05^{\circ} 2 \theta$ steps for $25 \mathrm{~min}$. Minerals were identified by the software package Diffracto plus (EVA and TOPAS) provided by Bruker Analytical XRay Systems (Bruker Corporation, Billerica, MA, USA). Scanning electron microscopic analyses were carried out on dried samples sputtered with Au using a Philips ESEM 5000 (Philips, Eindhoven, The Netherlands) having an elemental analysis system (EDAX) connected.

Table 1. Location of coring sites (from Wiesner et al., 2012).

\begin{tabular}{|c|c|c|c|}
\hline Site & Latitude [N] & Longitude [E] & $\begin{array}{c}\text { Water } \\
\text { Depth [m] }\end{array}$ \\
\hline 19 & $20^{\circ} 17.613^{\prime}$ & $109^{\circ} 08.266^{\prime}$ & 22 \\
\hline 23 & $21^{\circ} 05.838^{\prime}$ & $108^{\circ} 43.534^{\prime}$ & 27 \\
\hline 24 & $21^{\circ} 06.694^{\prime}$ & $108^{\circ} 43.792^{\prime}$ & 26 \\
\hline 26 & $21^{\circ} 03.421^{\prime}$ & $108^{\circ} 20.488^{\prime}$ & 28 \\
\hline 27 & $21^{\circ} 02.518^{\prime}$ & $108^{\circ} 18.151^{\prime}$ & 32 \\
\hline 28 & $20^{\circ} 49.763^{\prime}$ & $108^{\circ} 17.464^{\prime}$ & 40 \\
\hline 31 & $20^{\circ} 00.637^{\prime}$ & $108^{\circ} 05.476^{\prime}$ & 49 \\
\hline 32 & $19^{\circ} 59.529^{\prime}$ & $108^{\circ} 07.444^{\prime}$ & 66 \\
\hline 33 & $19^{\circ} 51.526^{\prime}$ & $108^{\circ} 20.382^{\prime}$ & 55 \\
\hline 34 & $19^{\circ} 27.453^{\prime}$ & $108^{\circ} 17.587^{\prime}$ & 59 \\
\hline 37 & $19^{\circ} 22.655^{\prime}$ & $107^{\circ} 41.945^{\prime}$ & 66 \\
\hline 38 & $19^{\circ} 25.059^{\prime}$ & $107^{\circ} 34.341^{\prime}$ & 65 \\
\hline 39 & $19^{\circ} 25.441^{\prime}$ & $107^{\circ} 21.333^{\prime}$ & 61 \\
\hline 40 & $19^{\circ} 25.034^{\prime}$ & $107^{\circ} 18.047^{\prime}$ & 58 \\
\hline 43 & $18^{\circ} 47.548^{\prime}$ & $107^{\circ} 09.967^{\prime}$ & 65 \\
\hline 44 & $18^{\circ} 44.227^{\prime}$ & $107^{\circ} 11.764^{\prime}$ & 67 \\
\hline 45 & $18^{\circ} 44.040$ & $107^{\circ} 16.236^{\prime}$ & 67 \\
\hline 51 & $18^{\circ} 22.809^{\prime}$ & $108^{\circ} 03.829^{\prime}$ & 75 \\
\hline 52 & $18^{\circ} 22.376^{\prime}$ & $108^{\circ} 03.873^{\prime}$ & 76 \\
\hline 54 & $17^{\circ} 53.425^{\prime}$ & $107^{\circ} 54.124^{\prime}$ & 91 \\
\hline 55 & $17^{\circ} 41.959^{\prime}$ & $108^{\circ} 07.020$ & 87 \\
\hline 57 & $17^{\circ} 38.420^{\prime}$ & $108^{\circ} 23.869^{\prime}$ & 109 \\
\hline 58 & $17^{\circ} 39.925^{\prime}$ & $108^{\circ} 24.997$ & 107 \\
\hline 60 & $16^{\circ} 43.544^{\prime}$ & $109^{\circ} 35.360^{\prime}$ & 553 \\
\hline
\end{tabular}

Sediments of four cores were chronometrically dated. For this purpose, in situ carbonate shells or plant remains were selected and cleaned, following the procedure of Tjallingii et al. (2010). The AMS C-14 measurements were carried out by the Leibniz Laboratory for Radiometric Dating and Isotope Research (Kiel, Germany). The measuring procedure is the same as described by Nadeau et al. (1997, 1998) and Tjallingii et al. (2010). Conversion of AMS C-14 ages into calendar years BP was calculated (Stuiver \& Polach, 1977) and calibrated by applying the IntCAL/Marine09 correction (Reimer et al., 2009). 


\section{RESULTS AND INTERPRETATION}

The average slope of the Gulf of Tonkin is rather uniform (ca $0.2 \mathrm{~m} / \mathrm{km}$ ), while the valley incised by the ancient Red River during last glacial sea-level lowstand shows a more variable gradient. Using detailed bathymetric data, the course of this valley was mapped (Fig. 2) as the seabed expression of valley system comprises depressions, which are incompletely filled (Fig. 3 ). The base of the channel is marked by a distinct reflector, and the fill of the main incised valley is normally 10 to $12 \mathrm{~m}$ thick, but the channel was about 5 to $12 \mathrm{~m}$ deep when sigmoidal reflectors formed (Fig. 3); they are overlain by stacked, convex downward reflectors. Above them, a pronounced discontinuity (MTS in Fig. 3) extends over the whole channel and forms the base of a package of parallel, approximately horizontal reflectors that reach up to the sea floor. The discontinuity corresponds to a clear lithological change in the cores.

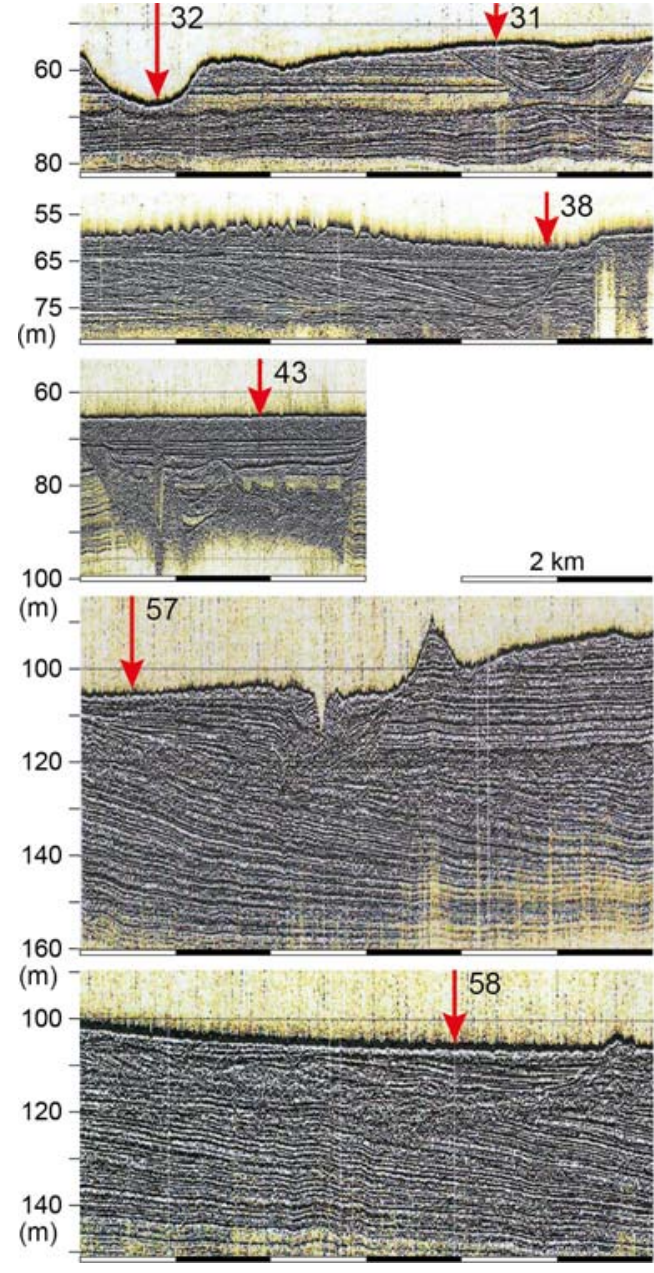

— Sequence boundary
- Sigmoidal reflector (example)
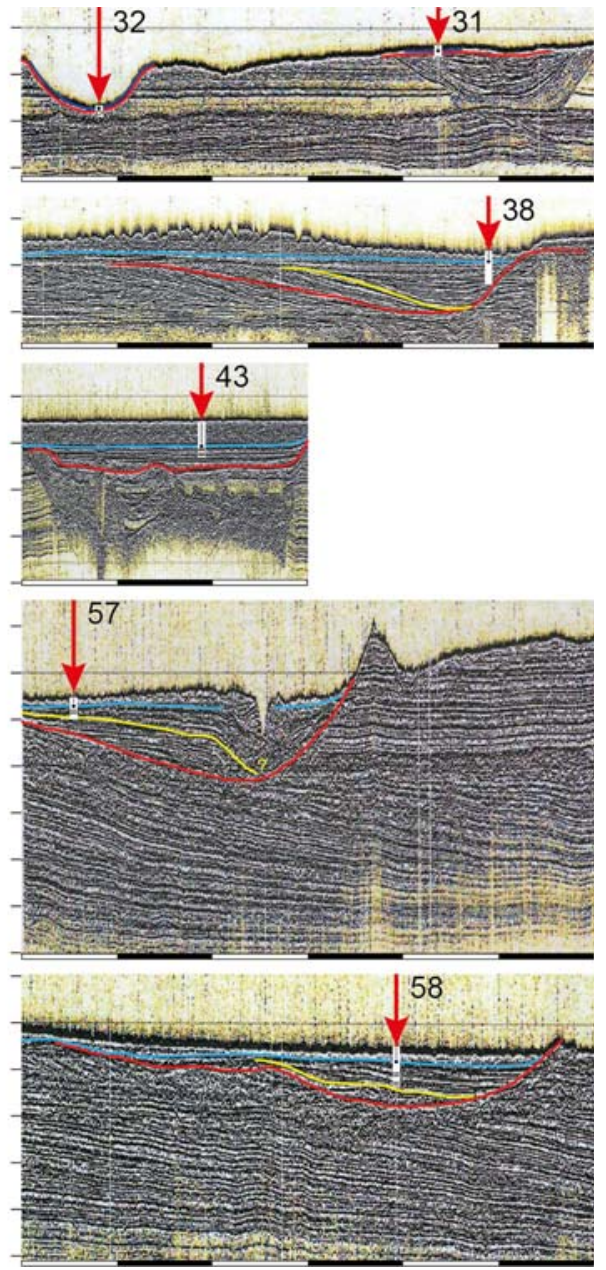

- Marine transgressive surface (MTS)

『) Lithofacies $5 \quad \cdot$ Lithofacies $4 \quad \square$ Lithofacies $3 \quad$ B Lithofacies $2 \quad$ Lithofacies $1+$ palaeosol

Fig. 3. Seismic sections traversing the valley incised by the ancient Red River and its tributaries during times of lowered sea-level. Bold numbers refer to sites (shown in Fig. 2). For all sections, horizontal and vertical scales are the same. Left - original records, right - some typical reflectors marked and lithofacies encountered in core (as defined below). For details, see text. 


\section{X-ray fluorescence core-scan data}

\section{Observations}

All cores of the incised-valley fill deposits exhibit a similar pattern of the XRF core-scan data with respect to the $\log (\mathrm{Ti} / \mathrm{Ca})$ values (Fig. 4). The lower unit is characterized by roughly uniform values around zero and it covers the lower half to two-thirds of the valley fill. Upward there is a transition to clearly negative, nearly constant $\log (\mathrm{Ti} / \mathrm{Ca})$ values, which are typical of the upper unit that extends to the sea floor. At the transition and somewhat below, some negative peaks may occur. The boundary between both units corresponds to the discontinuity (MTS) seen in seismic records (Fig. 3).

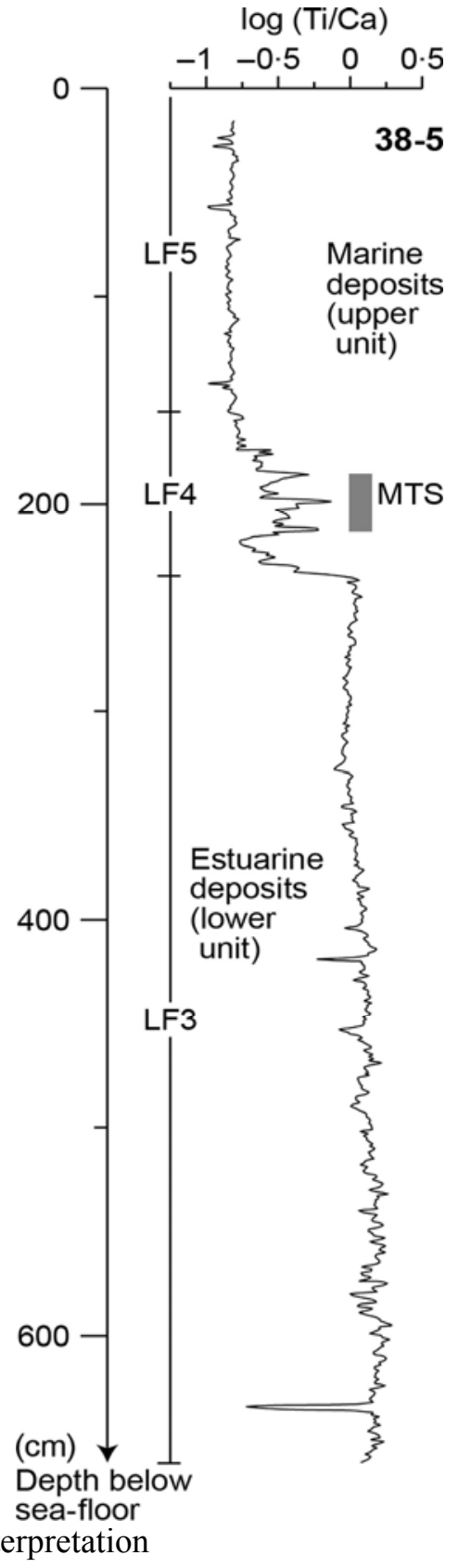

Fig. 4. X-ray fluorescence (XRF) scan data of core 38 taken in deposits filling a tributary to the valley incised by the ancient Red River (see Fig. 2 for location). Other cores exhibit a similar pattern and, therefore, are not shown. Slightly negative values at the top are typical of marine sediments (lithofacies LF 5 and LF 4), a transitional zone covers the marine transgressive surface (MTS), below, and slightly positive values are typical of purely terrigenous material, in this case estuarine mud (lithofacies LF 3). For details, see text. 
The relative variation of terrigenous and marine constituents can be approximated from the ratio of the elements titanium $(\mathrm{Ti})$ and calcium $(\mathrm{Ca})$. The conservative element $\mathrm{Ti}$ is restricted to lithogenic sediments and inert to diagenetic processes (Calvert \& Pedersen, 2007). The element $\mathrm{Ti}$ resides in $\mathrm{Ti}$ oxides, such as rutile and anatase ( $\mathrm{TiO} 2)$, and is enriched in tropical soils, such as laterites and bauxites. The element $\mathrm{Ca}$ mainly reflects the abundance of biogenic carbonates (CaCO3) in marine sediments (Arz et al.,1998; Tjallingii, 2007).

The $\log (\mathrm{Ti} / \mathrm{Ca})$ values around zero within the lower unit of the valley fill are typical of an abundance of terrigenous material and the absence of marine carbonates, whereas the slightly negative $\log (\mathrm{Ti} / \mathrm{Ca})$ values within the upper unit of the valley fill are typical of marine carbonate-containing sediments (e.g. Tjallingii, 2007; Fig. 4). Consequently, the lower unit is ascribed to a fluvial-estuarine depositional setting and the upper unit to marine conditions. The boundary between both units coincides with the discontinuity evident in the seismic records (MTS in Fig. 3) that, hence, represents the marine transgressive surface (= onset of full-marine conditions). The observed pattern of XRF core-scan data is very similar to that encountered for incised-valley fill deposits of the ancient Mekong River (e.g. Tjallingii et al., 2010).

\section{Diagenetic precipitates}

\section{Observations}

Early diagenetic siderite and Fe sulphides have been identified by XRD and ESEM-EDAX analyses, respectively (Fig. 5). These precipitates cut through physical as well as biogenic sedimentary structures. In fresh core, siderite is macroscopically visible while occurring in centimetre-sized bodies wherein light brownish fine-grained minerals are enriched. These bodies have diffuse margins and become increasingly brownish coloured and stiff towards the centre; they are oriented roughly parallel to bedding (Fig. 5A). Siderite is restricted to the lower unit of the incised- valley fill.


Fig. 5.

Diagenetic Fe-rich precipitates in fresh core (A) and X-ray radiograph negative (B), (site 54,332 to $352 \mathrm{~cm}$ ). Siderite (sid) appears brownish in fresh core (A) and as light nodules in X-ray radiograph negative (B), exhibiting in both cases diffuse margins. Fe sulphides (fes) are very thin, thread-like, often vertically oriented features, but macroscopically hardly visible, maybe as dark dots in fresh core (A); in X-ray radiograph negatives, they appear light and threadlike.

Iron sulphides appear as $<1 \mathrm{~mm}$ in diameter, 
thread-like bodies, black in fresh core and very light in X-ray radiograph negative (Fig. 5B). Their characteristics were described by Löwemark (2003), who named these precipitates 'pyrite' $\left(\mathrm{FeS}_{2}\right)$, although no detailed analysis was performed. In contrast, Kasten et al. (1998) identified such precipitates as greigite $\left(\mathrm{Fe}_{3} \mathrm{~S}_{4}\right)$. In this study, the mineralogy of the $\mathrm{Fe}$ sulphides was not determined. Iron sulphides occur in all cores already close to the base of the valley fill; however, further up, in siderite-bearing intervals, Fe sulphides are rare or absent. In some cores, intervals containing pyrite or siderite may alternate repeatedly.

\section{Interpretation}

The early diagenetic Fe-rich precipitates have environmental implications because siderite forms only in pore water low in sulphate (sulphide), typically, in freshwater-dominated settings (Postma, 1982). In contrast, Fe sulphides require sufficient sulphide in pore water; otherwise, they would not form and, therefore, they point to the influx of seawater (Rickard \& Luther, 2007). Hence, seawater incursions occurred already at least temporarily when the deposition of mud filling the incised valley started.

\section{Lithology and ichnology}

Basic results

Five lithofacies (LF) constitute the valley fill. The transitions between the lithofacies are bioturbated to varying degrees. The lower unit of the valley fill comprises lithofacies 1,2 and 3 , and the upper unit comprises lithofacies 4 and 5 (Fig. 6 and Table 2).

Biogenic sedimentary structures differ in fill (composition, grain size and colour), geometry and boundary to the surrounding sediment. Two general types are distinguished: (i) biodeformational structures having no distinct outlines which would allow their classification (Schäfer, 1956; Fig. 7A); and (ii) trace fossils (= distinct burrows) exhibiting a characteristic geometry that allows classification in terms of palaeontological nomenclature. The encountered burrows that can be ascribed to trace-fossil taxa are briefly described in Table 3 and shown in Fig. 7.

\section{Observations}

The typical succession of the incised-valley fill deposits consists (from bottom to top) of LF 1 to LF 5 (Fig. 8). Bioturbational structures are absent in the basal, up to 60 to $80 \mathrm{~cm}$ thick gravel to coarse sand of LF 1; LF 1 is overlain by mud that contains occasional iron sulphides (LF 2 or LF 2/3) and siderite, but in different intervals. The muddy LF 2 is not bioturbated and is restricted to specific sites that can be correlated in adjacent cores (Fig. 8). These intervals are up to 3 to $4 \mathrm{~m}$ thick and cluster in particular depth ranges (water depth at site + depth in core) at -116 to $-112 \mathrm{~m},-98$ to $-92 \mathrm{~m},-75$ to $-68 \mathrm{~m},-66$ to $-62 \mathrm{~m}$ and -34 to $-30 \mathrm{~m}$ (for details, see below).

Alternations of unbioturbated LF 2 and bioturbated LF 3 form composite up to $5 \mathrm{~m}$ thick packages of LF 2/3, in which the LF 2 intervals decrease upward in frequency and thickness from some tens of centimetres to centimetres. Hence, the average degree of bioturbation also increases upward. The intervals occupied by LF 3 are strongly bioturbated (40 to $60 \%$ ). The LF 2/3 intervals display a high proportion of biodeformation 

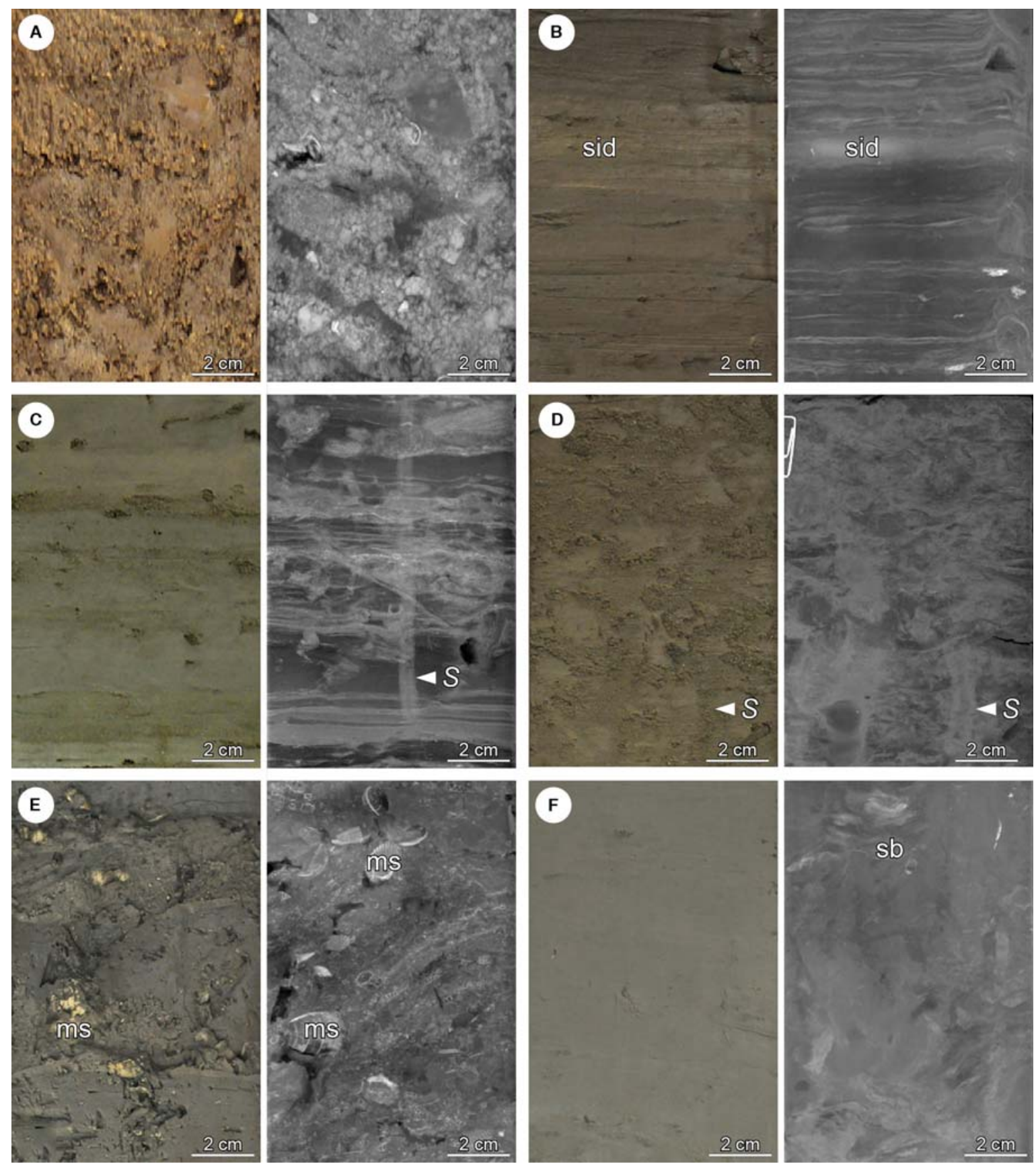

Fig. 6. Examples of lithofacies (LF), fresh core on the left, X-ray radiograph (negative; sand = light, mud = dark) on the right. (A) LF 1 - Fluvial lag deposits; note coarse texture and the presence of mud clasts (core 27-3, 953 to $965 \mathrm{~cm}$ ). (B) LF 2 - Laminated mud; laminae consisting of silt and fine sand are clearly seen in X-ray radiograph, whereas layers rich in organic debris cannot be distinguished; the latter, however, are evident in fresh core; sid = siderite (core 70-2, 248 to $260 \mathrm{~cm}$ ). (C) LF 2/3 - Thin alternating intervals consisting of bioturbated and laminated mud; $S=$ Siphonichnus (note its small size) (core 57-5, 397 to $409 \mathrm{~cm}$ ). (D) LF 3 - Bioturbated estuarine mud appearing homogeneous in fresh core exhibits biodeformational structures in X-ray radiograph both cross-cut by Siphonichnus burrows $(S)$ (core 38-5, 225 to $237 \mathrm{~cm}$ ). (E) LF 4 - Bioturbated muddy sand deposited just above the marine transgressive surface; originally deposited layers consisting of sand and shell debris (ms) were later mixed by burrowing organisms with mud (core 73-3, 268 to $280 \mathrm{~cm}$ ). (F) LF 5 - Bioturbated marine mud (core $68-3,163$ to $175 \mathrm{~cm}$ ); sb = siphonichnidal burrow. 
Table 2 Description and interpretation of encountered lithofacies (shown on Fig. 6)

\begin{tabular}{|c|c|c|}
\hline $\begin{array}{c}\text { Litho- } \\
\text { facies } \\
\text { (Figure) }\end{array}$ & Observations & Interpretation \\
\hline $\begin{array}{c}\text { LF } 1 \\
\text { (Fig. 6A) }\end{array}$ & $\begin{array}{l}\text { Greenish, grey, slightly muddy coarse-sandy } \\
\text { to pebbly material with mud clasts, carbonate } \\
\text { and Fe-oxide nodules; up } 60-80 \mathrm{~cm} \text { thick; no } \\
\text { burrows visible; discontinuously resting on } \\
\text { indurated Pleistocene mud; fairly sharp } \\
\text { boundary to LF } 2 \text { above. }\end{array}$ & $\begin{array}{l}\text { Fluvial lag deposits containing } \\
\text { remnants of palaeosols (caliche and } \\
\text { iron-oxide nodules); mud clasts } \\
\text { eroded from channel floor/banks; } \\
\text { discontinuity at the base representing } \\
\text { a sequence boundary. }\end{array}$ \\
\hline $\begin{array}{c}\text { LF } 2 \\
\text { (Fig. 6B) }\end{array}$ & $\begin{array}{l}\text { Greenish to grayish, locally brownish } \\
\text { laminated mud with thin laminae rich in dark } \\
\text { plant debris; thin silt and fine-sand layers } \\
\text { forming single laminae or packages, separated } \\
\text { by mud laminae or mm-thick mud intervals; } \\
\text { single } 3-5 \mathrm{~cm} \text { thick uniform mud layers } \\
\text { intercalated. LF } 2 \text { up to } 3-4 \mathrm{~m} \text { thick, but } \\
\text { restricted to specific sites and depth ranges } \\
\text { (for details see text). }\end{array}$ & $\begin{array}{l}\begin{array}{l}\text { Deposited under low-salinity } \\
\text { estuarine conditions (presence of }\end{array} \\
\text { siderite), affected by short-term } \\
\text { seawater incursions (presence of } \\
\text { pyrite); uniform mud layers } \\
\text { originating from fluid-mud having } \\
\text { formed at the interface between } \\
\text { fluvial and saline water. }\end{array}$ \\
\hline $\begin{array}{l}\text { LF } 2 \\
\text { (Fig. 6B) } \\
\text { LF } 3 \\
\text { (Fig. 6C) } \\
\text { LF 2/3 } \\
\text { (Fig. 6D) }\end{array}$ & $\begin{array}{l}\text { Endmembers: Laminated mud (LF 2) and } \\
\text { totally bioturbated mud (LF 3); up to several } \\
\text { cm-thick intercalating intervals of LF } 2 \text { and } \\
\text { LF } 3 \text { constituting LF } 2 / 3 \text {. No marine shell } \\
\text { (debris); siderite and/or Fe-sulfides present; up } \\
\text { to } 5 \mathrm{~m} \text { thick }\end{array}$ & $\begin{array}{l}\text { Terrigenous fluvial-estuarine mud } \\
\text { (see LF 2, LF 3); Fe-sulfides } \\
\text { implying marine influence, siderite } \\
\text { implying prevailing freshwater } \\
\text { conditions (for details see text). }\end{array}$ \\
\hline $\begin{array}{c}\text { LF } 3 \\
\text { (Fig. 6C) }\end{array}$ & $\begin{array}{l}\text { Grayish to greenish mud appearing visually } \\
\text { uniform; totally bioturbated; up to } 3-5 \text { m thick. } \\
\text { Size of burrows and degree of bioturbation } \\
\text { increasing towards the top; boundary to LF } 4 \\
\text { bioturbated to rather distinct (for details see } \\
\text { text). Fe-sulfides increasing upward; no } \\
\text { marine shells (except in burrows filled from } \\
\text { above by LF 4). }\end{array}$ & $\begin{array}{l}\text { Estuarine mud affected by recurrent } \\
\text { or even permanent seawater } \\
\text { incursion; upward increasing degree } \\
\text { of bioturbation (to nearly } 100 \% \text { at the } \\
\text { top) and Fe-sulfide content implying } \\
\text { increasing influence of seawater; } \\
\text { marine shell debris in burrows at the } \\
\text { top of LF } 3 \text { being burrowed } \\
\text { downward (for details see text). }\end{array}$ \\
\hline $\begin{array}{c}\text { LF } 4 \\
\text { (Fig. 6E) }\end{array}$ & $\begin{array}{l}\text { Greenish to pale, bioturbated, poorly sorted } \\
\text { fine to coarse sand containing considerable } \\
\text { amount of mud; (debris of) marine shells } \\
\text { common; only } 30-80 \mathrm{~cm} \text { thick; transition to } \\
\text { LF } 5 \text { gradational while bioturbated. }\end{array}$ & 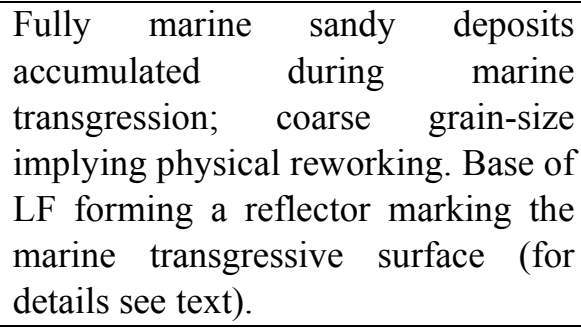 \\
\hline $\begin{array}{c}\text { LF } 5 \\
\text { (Fig. 6F) }\end{array}$ & $\begin{array}{l}\text { Visually uniform to slightly mottled greenish } \\
\text { mud; strongly bioturbated; lower proportion of } \\
\text { biodeformational structures and a higher } \\
\text { diversity of trace fossils than in LF } 3 \text {; marine } \\
\text { shell (debris) present; up to } 4 \mathrm{~m} \text { thick; } \\
\text { constituting modern seafloor. }\end{array}$ & Fully marine deposits. \\
\hline
\end{tabular}



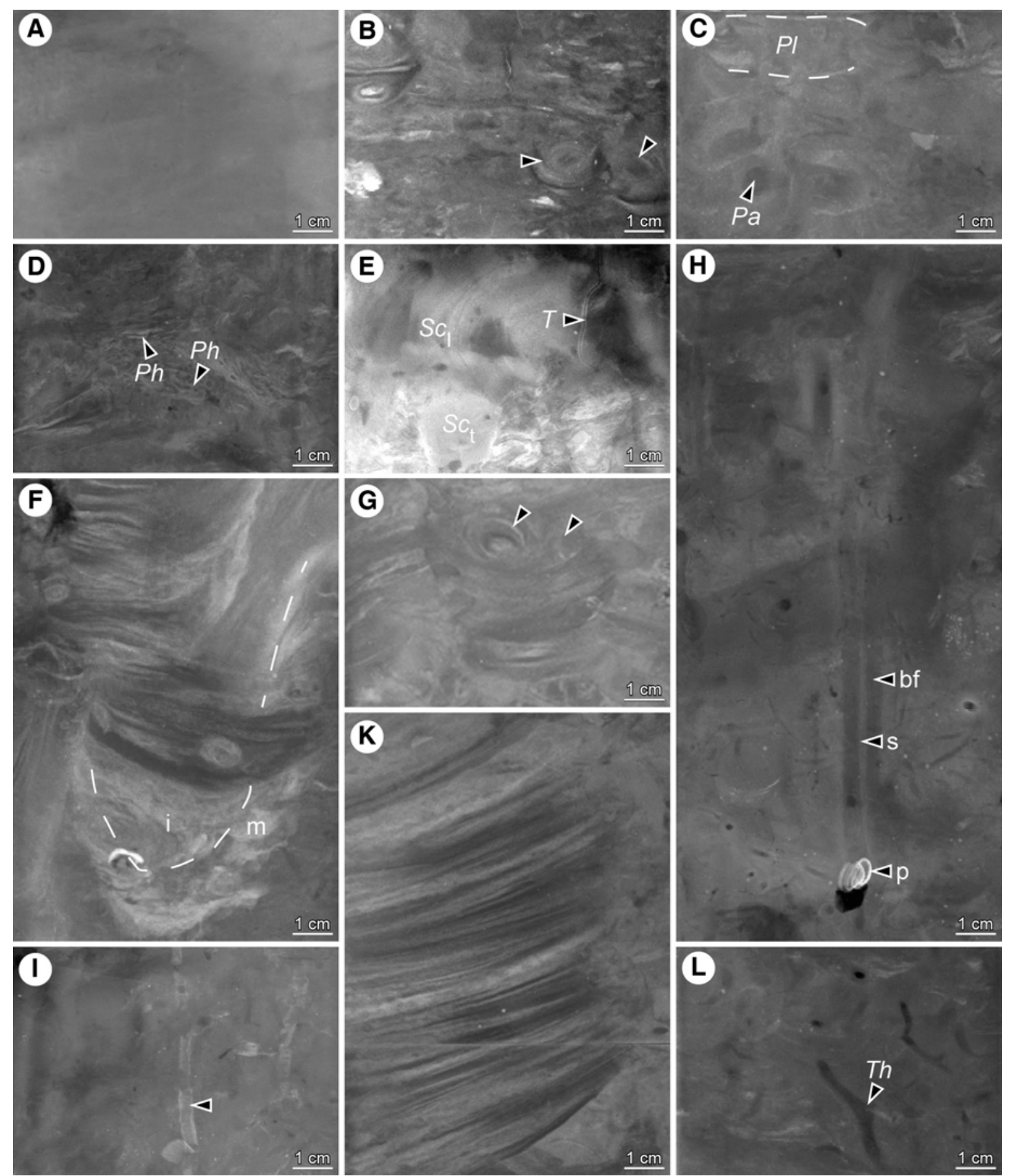

Fig. 7. Bioturbational structures (X-ray radiograph negatives). (A) Biodeformational structures (core 31-5; 141 to $148 \mathrm{~cm}$ ); (B) Artichnus and Asterosoma-like structures (core 38-5, 301 to $308 \mathrm{~cm}$ ), note the nearly concentric fill structure (arrows); (C) Palaeophycus (Pa) and Planolites (Pl) (core 43-3, 28 to $35 \mathrm{~cm})$; (D) Phycosiphon $(\mathrm{Ph})$ (core 52-1, 6 to $13 \mathrm{~cm})$, note the dark tube fill surrounded by light mantle (arrows); (E) Scolicia (Sc) and Trichichnus (T) (core 19-27, 1 to $8 \mathrm{~cm}$ ), Scolicia (Sc) in traverse section $\left(S_{C \mathrm{t}}\right)$ and longitudinal section $\left(S_{C 1}\right)$; (F) Scalichnus-like burrow (core 37-5, 56 to $70 \mathrm{~cm}$ ) consisting of a mantle (m) and inside of it a structured fill (i) (see Hanken et al., 2001); (G) siphonichnidal burrow (core 57-5, 154 to $161 \mathrm{~cm}$ ), arrows mark possible structures produced by two siphos; (H) Siphonichnus (core 42-2, 1 to $22 \mathrm{~cm}$ ), bf - backfill, s - trace of syphon, $\mathrm{p}$ - burrow producer; (I) Skolithos marked by arrow (core 28-1, 1 to $8 \mathrm{~cm}$ ); (K) Teichichnus (core 19-28, 114 to $128 \mathrm{~cm}$ ); (L) Thalassinoides (core 28-4, 113 to $120 \mathrm{~cm}$ ), Th marks tube enlargement at junction. 
Table 3. Description of trace fossils.

\begin{tabular}{|c|c|}
\hline Ichnogenus & Short description \\
\hline $\begin{array}{l}\text { Artichnus } \\
\text { and } \\
\text { Asterosoma- } \\
\text { like burrows }\end{array}$ & $\begin{array}{l}\text { Elongate, several cm long, } 1-2.5 \mathrm{~cm} \text { wide, bulbous, (sub)horizontally oriented } \\
\text { segments having an eccentrically laminated fill are interpreted as part of J-shaped } \\
\text { Artichnus (e.g., Zhang et al., 2008) that have some similarities with Asterosoma- } \\
\text { like burrows (e.g., Monaco, 2014); A. is produced by holothurians; A. occurs in LF } \\
3 \text { (upper part only), } 4 \text { and 5. }\end{array}$ \\
\hline Palaeophycus & $\begin{array}{l}\text { Branched or unbranched, lined, cylindrical burrow, fill structureless, of the same } \\
\text { lithology as host sediment (after Pemberton \& Frey, 1982). P. is } 0.5-1.5 \mathrm{~cm} \text { in } \\
\text { diameter and occurs in LF } 3,4 \text { and } 5 \text {. }\end{array}$ \\
\hline Phycosiphon & $\begin{array}{l}\text { Repeated narrow, U-shaped tubes enclose spreiten at mm- to cm-scale, branching } \\
\text { from an axial spreiten that shows various orientations; coarse material enriched in } \\
\text { spreiten and around tubes which have a muddy fill (e.g., Wetzel \& Bromley, } \\
\text { 1994). P. occurs only in LF 5, but not in the main incised valley. }\end{array}$ \\
\hline Planolites & $\begin{array}{l}\text { Rarely lined, unbranched, straight to tortuous, smooth to irregularly walled tubular } \\
\text { burrow having circular to elliptical cross-section; structureless fill differs from host } \\
\text { sediment (e.g., Pemberton \& Frey, 1982); burrow 0.5-2 cm in diameter. P. occurs } \\
\text { in LF } 3 \text { and 5. }\end{array}$ \\
\hline Scalichnus & $\begin{array}{l}\text { Vertical oriented, oval to circular structure having concave upward, nested } \\
\text { irregularly arranged laminae; outer part of fill pressed against wall, inner part often } \\
\text { deformed while passively infilled (Knaust, 2015); up to } 15 \mathrm{~cm} \text { deep and } 10 \mathrm{~cm} \\
\text { wide. S. occurs in LF 3, } 4 \text { and } 5 \text {. }\end{array}$ \\
\hline Scolicia & $\begin{array}{l}\text { Large, bilateral symmetrical, subcylindircal burrow having meniscate lamellae } \\
\text { often divided into two concave sets; today produced by Echinocardium-like sea } \\
\text { urchins (e.g., Bromley et al, 1997). S. occurs rarely and only in LF } 4 \text { and 5, but not } \\
\text { in the main incised valley. }\end{array}$ \\
\hline $\begin{array}{l}\text { Siphonichnus } \\
\text { and } \\
\text { siphonichnidal } \\
\text { burrows }\end{array}$ & $\begin{array}{l}\text { Vertical to inclined burrow with concave downwards or upwards meniscate } \\
\text { backfill, a vertical tube or pair of tubes penetrating the fill structure may be } \\
\text { present; circular to ellipsoidal in traverse section (after Zonneveld \& Gingras, } \\
2013 \text { ); } 1-2 \mathrm{~cm} \text { in diameter in LF } 4 \text {, } 5 \text {, but often smaller in LF } 2 / 3,3 \text {; penetration } \\
\text { depth up to } 1 \mathrm{~m} \text {. S. is produced by bivalves (Knaust, 2015). Burrows very similar } \\
\text { to } S \text {., but not matching ichnotaxon diagnosis exactly are called siphonichnidal } \\
\text { burrows. }\end{array}$ \\
\hline Skolithos & $\begin{array}{l}\text { Simple, straight unbranched, normally vertical tube having a uniform diameter (4- } \\
10 \mathrm{~mm} \text { ). S. occurs in LF } 3,4 \text {, and } 5 \text {. }\end{array}$ \\
\hline Teichichnus & $\begin{array}{l}\text { Long, wall-shaped, septate structures consisting of a pile of gutter-shaped laminae, } \\
\text { unbranched and oriented perpendicular or oblique to bedding. } T \text {. is } 10-15 \mathrm{~mm} \text { wide } \\
\text { and may penetrate }>15 \mathrm{~cm} \text { deep. } T \text {. only occurs in LF } 5 \text {, but not in the main incised } \\
\text { valley. }\end{array}$ \\
\hline Thalassinoides & $\begin{array}{l}\text { Slightly winding, semicircular, straight or curved, tube system having typical T- or } \\
\text { Y-shaped bifurcations being wider than tubes (two size classes of tube diameter, 4- } \\
6 \mathrm{~mm} \text { and } 20-30 \mathrm{~mm} \text { ). T. were formed during deposition of LF } 4 \text { and } 5 \text {, but may } \\
\text { penetrate down into LF } 3 \text {. }\end{array}$ \\
\hline Trichichnus & $\begin{array}{l}\text { Threadlike, thin-lined and rarely branching cylindrical burrow up to several tens of } \\
\text { centimetres long. Along the lining iron sulphides are preferentially precipitated } \\
\text { (e.g. Wetzel, 1981; Kędzierski et al., 2014). T. occurs in LF 2, 3, and 5. }\end{array}$ \\
\hline
\end{tabular}




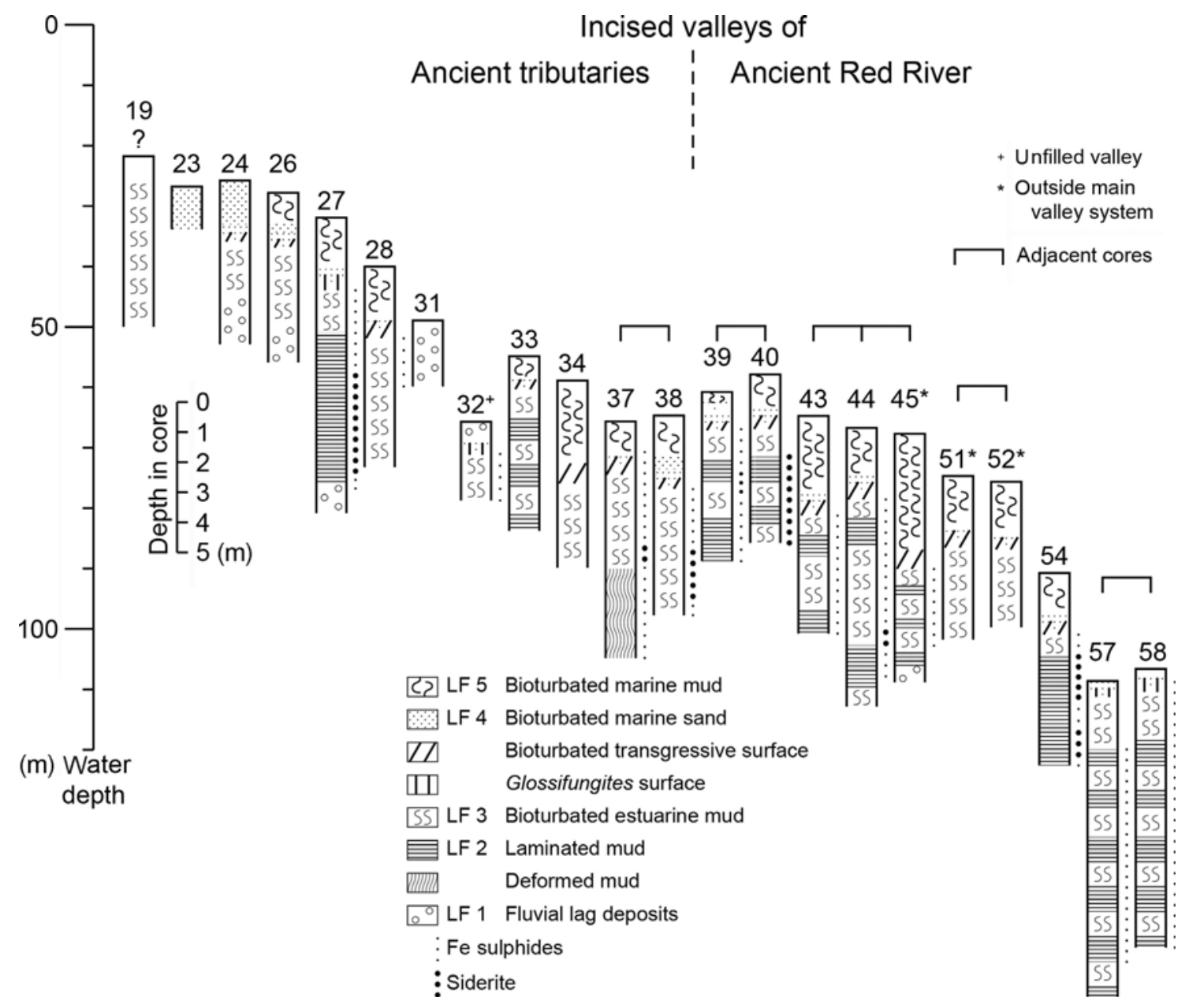

Fig. 8. Synoptic scheme of all cores studied. Cores are arranged along as a transect across the Gulf of Tonkin roughly from north to south, numbers refer to sites. For exact site location see Figure 2 and Table 1.

structures, of which two types have been distinguished: (i) homogeneous appearing domains (Fig. 7A); and (ii) patchy irregularly laminated domains (Fig. 9). The latter are rarely overprinted by other burrows. In LF $2 / 3$, the proportion of biodeformational structures may constitute ca 30 to $60 \%$ of the ichnofabric.

Bioturbation of estuarine mud (LF 3) increases upward: in the lower part, the degree of bioturbation is about 40 to $60 \%$, while in the upper part LF 3 is completely bioturbated; LF3 is up 3 to $5 \mathrm{~m}$ thick. Within LF 3 sideritic bodies decrease, and finally disappear, upward. In contrast, Fe sulphides increase upward and may dominate in the upper part of LF 3. Artichnus occurs only in the upper part of LF 3; LF 3 is characterized by a high proportion of biodeformational structures (ca 30 to 50\%) and siphonichnidal burrows. Commonly, the latter are small sized in the lower part of LF 3 or in LF $2 / 3$ (Fig. 6C). Siphonichnus $(>1 \mathrm{~cm}$ diameter) are common and may penetrate up to $1 \mathrm{~m}$ deep towards the top LF 3. Many of these burrows occur in a muddy substrate, but were actively filled with sand, although sand is no longer present within the interval from which the Siphonichnus originated (Fig. 10). The relative deep-penetrating siphonichnidal burrows obliterate a clear tiering pattern, and the 

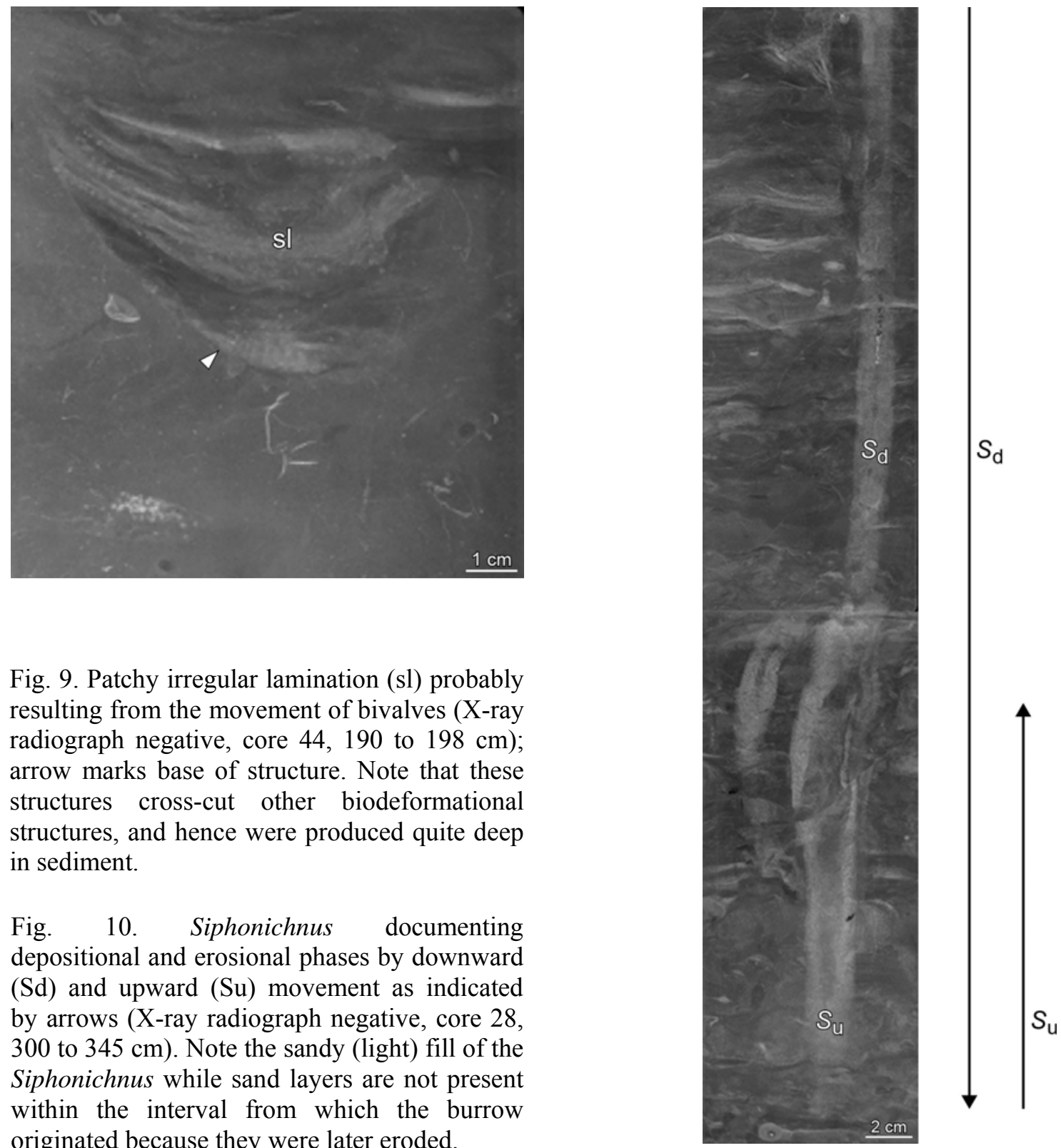

Fig. 9. Patchy irregular lamination (sl) probably resulting from the movement of bivalves (X-ray radiograph negative, core 44,190 to $198 \mathrm{~cm}$ ); arrow marks base of structure. Note that these structures cross-cut other biodeformational structures, and hence were produced quite deep in sediment.

Fig. 10. Siphonichnus documenting depositional and erosional phases by downward (Sd) and upward $(\mathrm{Su})$ movement as indicated by arrows (X-ray radiograph negative, core 28 , 300 to $345 \mathrm{~cm}$ ). Note the sandy (light) fill of the Siphonichnus while sand layers are not present within the interval from which the burrow originated because they were later eroded.

observed cross-cutting relationships, however, imply three tiers comprising: (i) shallow mixed-layer biodeformational structures; (ii) intermediate Palaeophycus and Planolites; and (iii) Siphonichnus, Artichnus, Asterosoma(-like) and siphonichnidal burrows. Within the estuarine lithofacies, there are no clearly developed discontinuities, no distinct layers significantly enriched in coarse components and no horizons exhibiting primary structures typical of tidal influence: LF 3 is always present beneath sandy LF 4.

Lithofacies 4 is composed of muddy sand and contains marine shell debris; LF4 is only 30 to $80 \mathrm{~cm}$ thick. The boundary between LF 3 and LF 4 is totally bioturbated; two types of development have been found. In most cases, the transition is gradational and mud-filled burrows become less abundant while sand-filled burrows become common. However, in about $110 \mathrm{~m}$ and $30 \mathrm{~m}$ water depth, the boundary is marked by the Glossifungites ichnofacies 
(cf. Pemberton \& Frey, 1985; Uchman et al., 2000; see below). In this case, the top of LF 3 consists of stiff mud that is penetrated by sharpwalled burrows, of which a few are still open, while others are filled with sediment from the overlying LF 4 (Fig. 11). The transition between estuarine and marine deposits is characterized by marked fluctuations of the $\log (\mathrm{Ti} / \mathrm{Ca})$ value. Negative peaks coincide with burrows filled with marine sediments, whereas values around zero are typical of the estuarine host sediment (Fig. 11). Lithofacies 4 is completely bioturbated; biodeformational structures, large Thalassinoides and Siphonichnus occur. The transition to LF 5 is gradational while bioturbated.

Lithofacies 5 comprises completely bioturbated impure mud with marine shell debris and is up to $4 \mathrm{~m}$ thick. Lithofacies 5 contains a more diverse suite of trace fossils than LF 3 (because LF 2 and 1 are unbioturbated). In particular, Phycosiphon, Scolicia, Teichichnus and Thalassinoides occur in LF 5. The average size of burrows in LF 5 is larger than in LF 3. For example, in the lower part of LF 3 siphonichnidal burrows of small size (3 to $10 \mathrm{~mm}$ diameter) dominate (Fig. 7C), while in LF 5 these burrows may reach $2.5 \mathrm{~cm}$ diameter in full-marine deposits. Because of the high proportion of vertical oriented burrows, a tiered ichnofabric is not clearly developed as a common and recurrent cross-cutting pattern of the traces is not obvious. Tiering was deciphered from occasional intersection of the different burrow types. In an idealized case, five tiers can be distinguished (from the top downward): (i) mixed-layer biodeformational structures; (ii) Palaeophycus and Planolites; (iii) Scalichnus, Siphonichnus and Teichichnus; (iv) Thalassinoides; and (v) Artichnus, Asterosoma(like) and siphonichnidal burrows.

\section{Interpretation}

The change from gravelly to coarse-sandy fluvial lag deposits of LF 1 to estuarine mud (LF 2 and LF 3) that occasionally contains $\mathrm{Fe}$ sulphides records a considerable shift from a high-energy bypass sedimentary system to an aggrading



Fig. 11. A Glossifungites surface separates lithofacies 4 (LF 4; marine sandy deposits) above from lithofacies 3 (LF 3; estuarine mud) and hence represents a transgressive surface. The burrows belonging to the Glossifungites suite (Thalassinoides, Th) are filled with marine sediment from above that is characterized by slightly negative peaks in the XRF core-scan data (X-ray radiograph negative, core 27, 211 to 286 $\mathrm{cm})$. The sharp margins of the Glossifungites suite burrows indicate that traces were produced in stiff sediment. 
depositional setting. This decrease in hydraulic energy is interpreted to record the onset of base-level rise. Furthermore, the presence of Fe sulphides implies the presence of sulphaterich seawater. Consequently, the onset of mud deposition and sediment aggradation occurred under estuarine conditions. The intercalation of intervals that contain siderite or Fe sulphides documents fluctuations between low-salinity and high-salinity conditions, respectively. In organic-rich and Fe-rich mud, low amounts of sulphate are removed by sulphate reduction and, after Fe sulphide, siderite may precipitate within the same or an adjacent interval. Ephemeral and seasonal, monsoon-driven low freshwater discharge, exceptional tides or storms could have caused seawater incursion. In particular, far upstream seawater incursion is facilitated during low discharge, when a saltwater wedge may form in deep incised channels (e.g. Poggioli \& Horner-Devine, 2015). For instance, in the Southwest Pass of the Mississippi River, seawater flows $235 \mathrm{~km}$ upstream during low discharge while the tidal range is only 36 cm (Schubel \& Meade, 1977). During high discharge, the estuarine circulation changes to mixing conditions because of high turbulence. During these times, seawater intrudes a maximum of a few (tens of) kilometres.

The fluctuating boundary of seawater incursion due to fluvial discharge variations affects mud deposition and may enhance mud dominance in the incised-valley fill. At the interface of seawater and freshwater, the high ion strength of seawater favours the flocculation and deposition of mud (e.g. Sutherland et al., 2015). In modern settings, mud deposition is greatest at the turbidity maximum and decreases in seaward and landward directions (e.g. La Croix \& Dashtgard, 2014). The turbidity maximum is located at the freshwater to brackishwater transition zone that coincides with the landward tip of the seawater tongue (La Croix \& Dashtgard, 2014). Downstream from the backwater limit, freshly deposited mud could have been remobilized at elevated current velocity when river run-off and ebb-tidal currents interacted (e.g. Kostaschuk et al., 1992; Dalrymple et al., 2012). Furthermore, observations in modern estuaries show that during onset of the freshet (= high flood period), the river is dominantly in an erosive stage. As freshet proceeds, the river shifts from erosion and sediment bypass to a stage of sand deposition. As the freshet flow wanes, mud is deposited until the bulk of the freshet-induced sediment load in the river is exhausted (La Croix \& Dashtgard, 2014).

A lack of bioturbation in the muddy LF 2 implies particular environmental conditions. In estuarine settings, mainly salinity affects the fauna (Remane, 1934): at low or strongly varying salinity, fauna becomes impoverished, particularly when salinity fluctuations range from freshwater to seawater (e.g. Lalli \& Parsons, 1993; Gingras et al., 2012). The same is true for the ichnofauna (see summary by, e.g. MacEachern et al., 2009; Díez-Canseco et al., 2016). Such environmental conditions lead to a decrease in diversity, size and penetration depth of burrows (e.g. MacEachern et al., 2009).

Therefore, the composite LF $2 / 3$ is interpreted to document short-term seawater incursion into the estuarine, low-salinity to freshwater depositional system within the incised valley: the laminated intervals represent stressful conditions for the fauna, characterized by low or fluctuating salinity, high turbidity and soupy sediment consistency, while bioturbation took place during episodes of at least upper mesohaline to polyhaline conditions (e.g. DíezCanseco et al., 2016). Short-term sedimentation events might have taken place as well. Although the bioturbated layers are several centimetres thick or more, the periods of 
bioturbation were rather short, because the burrowing animals penetrated several centimetres down into the sediment from their colonization level (e.g. Wetzel, 1981).

Intervals occupied by LF 2 and LF $2 / 3$ were encountered only in specific depth ranges that can be correlated in adjacent cores (see above; Fig. 8). When compared to the composite sealevel curve for the South China Sea (Tjallingii et al., 2010, 2014; Fig. 12), the LF 2 and LF $2 / 3$ intervals formed during both times of 'average' sea-level rise at a rate of ca $10 \mathrm{~mm} / \mathrm{year}$ and times of rapidly rising sea-level at Meltwater Pulse 1A and 1C ( $>40 \mathrm{~mm} /$ year from -100 to $-80 \mathrm{~m}$ and $>20 \mathrm{~mm} /$ year from -32 to $-10 \mathrm{~m}$, respectively). The valley segments wherein these intervals occur have a comparatively gentle inclination followed by an increase in slope upstream (Fig. 12). The latter hindered upstream incursion of seawater and, hence, flocculation and deposition of mud were enhanced downstream, in the gently inclined channel parts. The resultant high sedimentation rate and soupy sediment consistency reduced the burrowing fauna and favoured deposition of laminated mud.

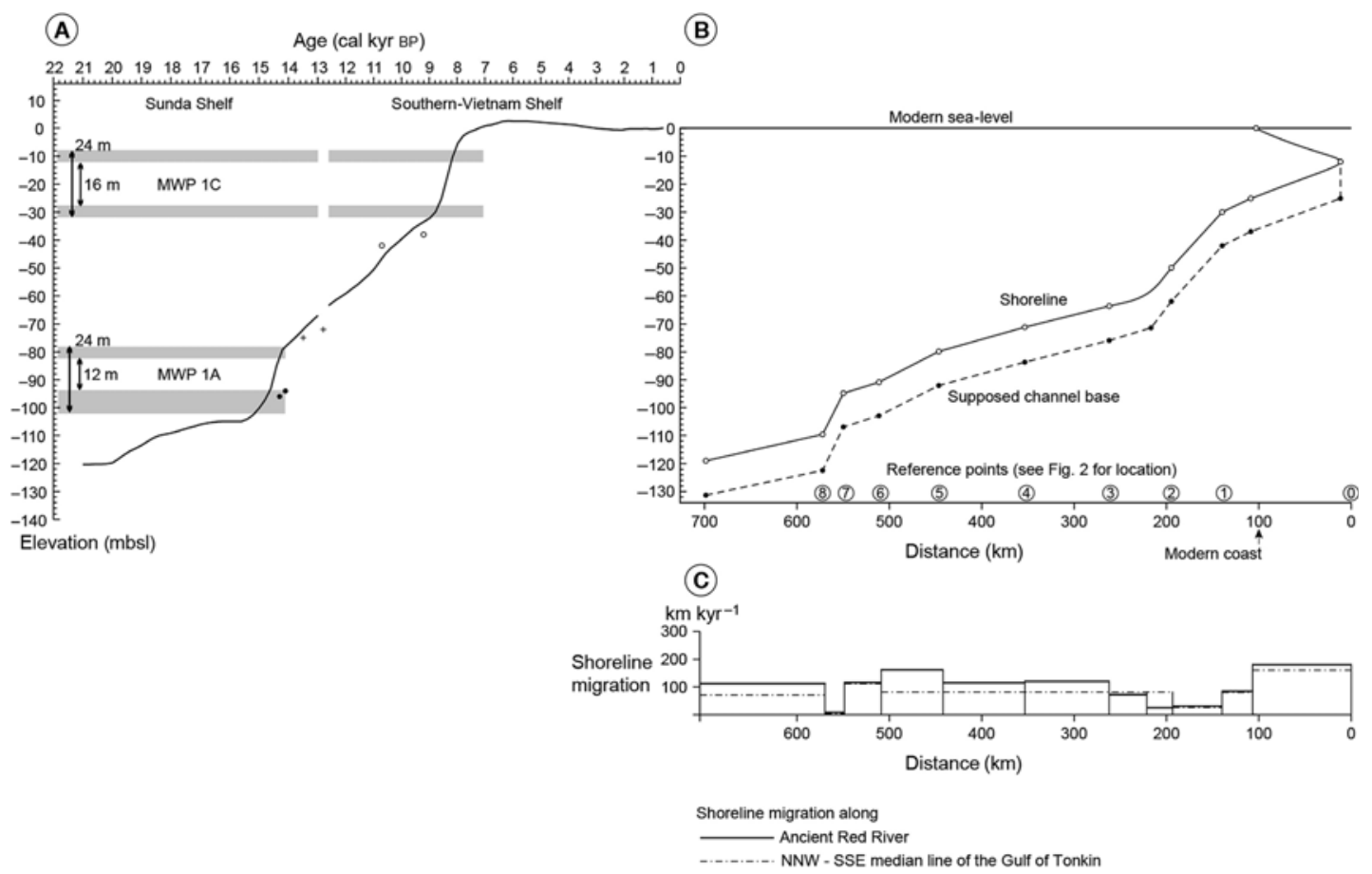

Fig. 12. Holocene sea-level rise in the South China Sea (A) and relief of the Gulf of Tonkin (B) and rate of coastline migration (C). (A) Sea-level curve based on data obtained from the Sunda Shelf (20 to $12 \mathrm{ka}$; Hanebuth et al., 2000), offshore the present-day Mekong Delta (12 to $7 \mathrm{ka}$; Tjallingii et al., 2010, 2014) and the shoreline of southern Vietnam (Stattegger et al., 2013); chronometric age data from the present study are marked with dots (core 54), crosses (core 45) and open circles (core 27). (B) Bathymetric transect along the valley incised by the ancient Red River based on GEBCO (2015), shipboard data and data of Hori et al. (2004) close to the modern Red River delta and Tanabe et al. (2006) within the delta region; encircled numbers refer to reference points in Fig. 2. Reference point (0) refers to maximum inland extent of the coastline at around $9 \mathrm{ka}$ after Tanabe et al. (2006). (C) Rate of coastline migration during Holocene transgression along the valley incised by the ancient Red River (solid line) and roughly along the median line from the open ocean to the modern Red River delta (broken line; for location see Fig. 2); rate of coastline progradation since ca 9 ka is not shown. MWP $=$ Melt Water Pulse. 
Within intervals occupied by LF 3, the marine influence increases upward as recorded by the disappearance of siderite and an increase in $\mathrm{Fe}$ sulphides. The increasing influence of seawater finally favoured complete bioturbation (e.g. Dashtgard et al., 2012; Table 2). Another indication for such conditions is the occurrence of Artichnus (cf. Ayranci \& Dashtgard, 2013) that is produced by sea cucumbers, which live mainly in marine, but also in brackish settings, having a salinity tolerance as low as 20\& (e.g. HELCOM, 2012; Smilek \& Hembree, 2012). However, the absence of primary sedimentary structures typical of tidal influence and of a marked discontinuity within the estuarine deposits documents a suppressed or small influence of tidal currents (for discussion, see below).

The boundary between LF 3 and LF 4 represents a marine transgressive surface (MTS in Fig. 3), confirmed by the presence of marine shells in LF 4, but their absence in LF 3. Besides, shells and sand content are both enriched in LF 4, reflecting greater wave reworking and winnowing of fines. The transition of LF 3 to LF 4 matches the criteria of a wave ravinement surface (WRS; e.g. Zaitlin et al., 1994; Cattaneo \& Steel, 2003), including the increase in grain size and reduced thickness.

Evidently, during transgression, mud was winnowed when ocean waves and currents affected this part of the estuary. The lowest wave activity is represented by a bioturbated contact and occurs in the gently inclined channel segments (Figs 8 and 12). The gentle slope favoured dissipation of hydraulic energy (cf. Davis \& Fitzgerald, 2004). In steeper inclined channel segments, the Glossifungites ichnofacies was encountered (Figs 8 and 12). The stiff sediment consistency and the sharp-walled, occasionally open burrows imply that considerable erosion took place prior to deposition of the marine sediment (e.g. Pemberton \& Frey, 1985). Within these channel parts, waves might have shoaled.

For the variation in slope of the incised valley, there are two explanations: (i) they reflect previous knickpoints formed during backward incision; or (ii) they resulted from tectonic movements along the Red River Fault Zone, while slight lateral tectonic movements can result in vertical displacement of blocks (e.g. Mitchell \& Reading, 1986;

Gong et al., 2011; Fyhn \& Phach, 2014). Unfortunately, the shipboard seismic records are not sufficient to verify either hypothesis.

The higher diversity of trace fossils in marine compared with estuarine deposits matches observations from both modern and ancient settings (e.g. MacEachern et al., 2009; Gingras et al., 2012). Phycosiphon and Scolicia have only been described from marine sediments (e.g. Buatois et al., 2008). While the producer of Phycosiphon is unknown, modern Scolicia are known to be produced by sea urchins (e.g. Bromley et al., 1997). Thalassinoides and Teichichnus have been observed in brackish-water and marine deposits (e.g. Buatois et al., 2008; Pemberton et al., 2010). Teichichnus and Thalassinoides were probably not produced in this salinity-stressed setting because of the soft sediment consistency and high sediment mobility.

Significance of Siphonichnus burrows

These and related traces have been reported from a wide variety of modern and ancient depositional settings experiencing at least some marine influence, such as in deltaic, intertidal, 
estuarine and other inshore coastal environments (see summary by Zonneveld \& Gingras, 2013). Siphonichnus is very rarely described from lacustrine successions (Fouch \& Dean, 1982). The occurrence of Siphonichnus in the Red River incised-valley fill deposits is interpreted to indicate at least some marine influence, as in other estuarine settings (e.g. Lettley et al., 2009). There, siphonichnids are of relatively small size as in comparable modern settings (cf. Johnson \& Dashtgard, 2014, fig. 9). The population structure of modern infaunal bivalves in brackish environments supports this interpretation (see Pemberton et al., 2001, fig. 122).

Siphonichnus-producing bivalves maintain contact with the sediment-water interface using syphons. For modern taxa, the syphons range from a few millimetres to over a metre in length (Ricketts et al., 1985). Long Siphonichnus are rarely observed completely (e.g. Knaust, 2015). Siphonichnus and related burrows document vertical movement of their producers, which respond to episodic erosion or deposition in dynamic sedimentary settings. These traces are, therefore, classified as equilibrichnia (Zonneveld \& Gingras, 2013). In the studied rapidly aggrading deposits, many Siphonichnus producers burrowed downward. There are two explanations for the deep penetration. Firstly, the producers moved downward after they started to explore the habitat to reach optimum living conditions. Alternatively, the incisedvalley fill deposits experienced episodic erosion and the Siphonichnus producers responded to that; this is particularly true for those Siphonichnus that occur in mud, but have been actively filled with sand (Fig. 10). Evidently, sand was present when the Siphonichnus producers burrowed downward and fed from the sediment surface, but it was eroded later and is now only preserved in Siphonichnus. Such Siphonichnus are highly suggestive of significant erosion that may occur in estuarine settings, when river run-off and ebb-tidal currents interact or during freshet (e.g. Kostaschuk et al., 1992; La Croix \& Dashtgard, 2014).

The burrowing activity of bivalves is probably also documented by the well-preserved and, hence, deeply produced patchy irregularly laminated biodeformational structures (Fig. 9). These structures are very similar in many aspects to 'plough-sole' burrows produced by horizontally moving bivalves described by Werner (2002) and Winn (2006) from modern brackish-water deposits in the Baltic Sea. These bioturbational structures have a rather sharp, often convex downward lower boundary and exhibit an irregularly laminated fill, which shows a gradational transition to the sediment above that partly collapsed into the open space left behind the moving bivalve.

The formation of a tiered ichnofabric was counteracted by the producers of siphonichnidal burrows that moved upward and downward. Deep burrowing is a strategy of infaunal organisms to survive in brackish environments affected by salinity oscillations, because the amplitude of fluctuations decreases with depth in sediment (e.g. Knox, 1986). The low degree of bioturbation in the upper tiers supports this reasoning. Deep burrowers form an important part of the infaunal community in brackish-water deposits (e.g. Lettley et al., 2009).

\section{DEVELOPMENT OF VALLEY FILL AND SEQUENCE STRATIGRAPHY}

The typical succession of the incised-valley fill deposits consists (from bottom to top) of the following: (i) fluvial lag deposits; (ii) unbioturbated to bioturbated estuarine mud; (iii) thin fully marine muddy sand with marine shell debris; and (iv) fully marine mud (Fig. 13). The 
thin nature of LF 4 (only a few tens of centimetres) composed of completely bioturbated impure sand implies that, during sea-level rise, the mouth of the ancient Red River represented a funnel-shaped open estuary (Fig. 14). There is no evidence, either in the seismic records or in the cores, that a sandy estuarine barrier system or tidal sand bars developed. Even if reworking occurred during transgression, it was commonly too low to result in an erosional surface (accentuated by Glossifungites suite burrows). Consequently, only three facies zones were present, fluvial (LF 1), estuarine (LF 2 and LF 3) and full marine (LF 4 and LF 5). Such a setting differs from both 'standard' endmembers: wave-dominated (e.g. Zaitlin et al., 1994) and tide-dominated estuaries (e.g. Dalrymple et al., 2012). Both of these possibilities need to be investigated because the modern Red River delta displays characteristics of both, wave dominance in the south and tide dominance in the north (e.g. Duc et al., 2007). A sandy barrier system and sandy tidal bars may not have developed for several reasons: (i) the coastline migrated very rapidly landward (50 $\mathrm{m}$ to $>100 \mathrm{~m} / \mathrm{year}$ ) by aggressive wave ravinement, enhanced by the Gulf of Tonkin's gentle slope (ca $0.2 \mathrm{~m} / \mathrm{km}$; Fig. 12); (ii) the Red River carries little bed load resulting in an absence of estuary mouth sand bars; and (iii) little erosion of a gently inclined, mud-dominated coast occurred (e.g. Davis \& Fitzgerald, 2004), resulting from negligible sand supply from longshore currents (e.g. Meade, 1969; Allen, 1991; Duc et al., 2016). The latter two factors resulted in a lack of sand-grade sediment. Therefore, during Holocene transgression, the mouth of the ancient Red River formed essentially a drowned-valley estuarine system that was both mud-dominated and of relatively low energy (cf. Dalrymple et al., 1992, fig. 12). Using the classification of Perillo (1995), this would represent a coastal plain type, funnel-shaped, river-influenced primary estuary.



Fig. 13. Schematic, synthetic lithological $\log$ of the mud-dominated deposits filling the valley incised by the ancient Red River in the Gulf of Tonkin. The thickness of the lithofacies may vary in response to valley gradient; here average values are shown (for details, see text). Numbers referring to lithofacies types as explained in text and shown in Fig. 6; sequence stratigraphic abbreviations

$\mathrm{SB}=$ sequence boundary;

$\mathrm{TS}=$ transgressive surface;

MTS $=$ marine transgressive surface;

$\mathrm{MFS}=$ maximum flooding surface that in fact is not sharply defined, rather representing an interval;

LST $=$ lowstand systems tract;

TST $=$ transgressive systems tract;

HST $=$ highstand systems tract. 
In terms of sequence stratigraphy, the thin fluvial lag sediments represent a remnant of the lowstand systems tract (LST) deposits. While incised into consolidated Pleistocene deposits, the erosional surface related to LF 1 has to be classified as sequence boundary (SB). Subsequently, base level started to rise as recorded by aggrading estuarine mud (LF 2 and LF 3). The aggrading nature of these lithofacies is evident in the seismic records (Fig. 3). Consequently, the transgressive surface is located above LF 1 . These deductions match observations in modern and ancient incised valleys (e.g. Zaitlin et al., 1994). The part of the incised-valley fill that is characterized by stacked or sigmoidal reflectors formed only during the transgressive systems tract (TST) within the fluvial-estuarine transition zone as, for instance, suggested by Reynaud et al. (1999). The sigmoidal reflectors probably represented muddy river-bank attached bars. Such geometry of mud-dominated sediments has been described from modern estuarine settings within the mouth of the Fraser River (La Croix \& Dashtgard, 2014). A tidal ravinement surface (TRS; sensu Zaitlin et al., 1994) did not develop, as documented by the absence of strong tidal influence and of a discontinuity within the estuarine facies, as explained above.

The boundary between estuarine (lower unit) and full-marine deposits (upper unit) represents a marine transgressive surface (MTS), in particular a wave ravinement surface (WRS; see above). At some sites, the formation of the marine transgressive surface can be assessed. Taking into account the average slope of the land surface and the water level within the channel, as given by sigmoidal reflectors (Fig. 3, Section 38), the transgressive surface formed about 1 to $5 \mathrm{~km}$ landward of the coastline while the coastal plain was about $2 \mathrm{~m}$ above the top of the sigmoidal reflectors.

The maximum flooding surface (MFS) formed in the area of the modern Red River mouth at around $8.6 \mathrm{ka}$ (Tanabe et al., 2006). However, all cores were taken in water depths $>24 \mathrm{~m}$ (a level that was reached shortly after $9.0 \mathrm{ka}$ during the last phase of accelerated sea-level rise; Tjallingii et al., 2014; Fig. 12). In the studied cores, the $8.6 \mathrm{ka}$ time level, thus, is located somewhere in completely bioturbated, uniform marine mud (LF 5). Hence, the Holocene MFS does not form a distinct horizon in the studied deposits.

\section{DISCUSSION}

In response to falling sea-level, a river traversing a cohesive substrate incises backward to approach a new equilibrium, which starts from the actual base level at the river mouth (e.g. Schumm, 1993). With respect to backward incision, three channel segments can be distinguished: (i) close to the sea, where equilibrium has been reached; (ii) a segment accentuated by a knickpoint, where backward incision is active; and (iii) upstream reaches that are not affected (e.g. Loget \& Van Den Driessche, 2009).

The final phase of the last glacial sea-level drop with $40 \mathrm{~m}$ in 4000 years down to the last glacial maximum (LGM) lowstand and the maximum 6000 years duration of the LGM (Peltier \& Fairbanks, 2006; Hanebuth et al., 2009) greatly outpaced fluvial incision. Consequently, river channels on the newly exposed shelf did not have time to reach geomorphic equilibrium (e.g. Schumm, 1993; Fagherazzi et al., 2004; Loget \& Van Den Driessche, 2009). Therefore, the entire length of the developing incised valley is characterized 
by (net) fluvial erosion (e.g. Zaitlin et al., 1994). When a river segment that did not reach geomorphic equilibrium becomes affected by the interaction of ebb currents and run-off within the backwater limit during sea-level rise, the temporary increase in stream power may enhance erosion of previous deposits. This scenario explains the absence of fluvial sediments other than lag deposits. The presence of Fe sulphides above the fluvial lag deposits records the onset of sediment aggradation in a setting already impacted by sea-level rise and seawater incursion. These observations match the model of Zaitlin et al. (1994), which suggests a coincidence of the basal sequence boundary and the flooding surface. Both form a coplanar surface and imply that purely fluvial deposits (except the lag sediment) are absent in some incised-valley fills.

In a gently inclined valley segment seawater can intrude upstream for a longer distance than in a steeply inclined segment, especially at low discharge in a channel having uniform geometry (e.g. Poggioli \& Horner-Devine, 2015). Seawater incursions in response to strongly fluctuating fluvial discharge lead to recurrent salinity changes induce flocculation and deposition of water-rich, soft to fluid mud at the interface between river and seawater. This may enhance sediment mobility when ebb tides and river runoff interact (e.g. Dalrymple et al., 2012). All of these factors affect the (endo)benthic fauna (e.g. MacEachern et al., 2009; Buatois \& Mángano, 2011) and lead to a lower diversity, overall smaller body (burrow) size and a lower degree of bioturbation, as documented in LF 2/3 and LF 3. Therefore, intervals characterized by stressful conditions for the benthic fauna can be correlated within the same channel segment.

Downstream of the backwater limit, there were alternating phases of deposition and erosion, as indicated by the Siphonichnus equilibrichnia. Fluctuations in discharge are known to cause such a dynamic sedimentary setting (La Croix \& Dashtgard, 2014). Towards the top of LF 3, the environment became increasingly affected by seawater and ecological stress decreased as indicated by complete bioturbation and an increase in the size of burrows. Sediment accumulation was rapid, as in many modern estuaries and indicated by vertically stacked reflectors, where sediment aggradation in the channel occurs downstream of the turbidity maximum (Dalrymple et al., 2012; Sutherland et al., 2015).

For the Holocene transgression, the rate of coastline migration can be assessed by relating sea-level rise to topography. For the Gulf of Tonkin, the coastline migrated at an average rate of $59 \mathrm{~m} /$ year; a distance of $700 \mathrm{~km}$ from the $120 \mathrm{~m}$ isobath to the landward apex of the modern delta was transgressed over $12 \mathrm{kyr}$ (Fig. 12). However, Holocene sea-level rise was not constant and topography of the Gulf of Tonkin is variable. Two transects are addressed to illustrate this: (i) the roughly SSE-NNW-directed median line of Gulf of Tonkin from the open sea to the Red River Delta; and (ii) a section along Red River incised valley (Figs 2 and 12). On average, the shoreline migrated landward at a rate of ca $60 \mathrm{~m} /$ year reaching a maximum of ca $80 \mathrm{~m} /$ year. However, the mouth of the ancient Red River migrated more rapidly at $100 \mathrm{~m} /$ year on average with a maximum rate of $150 \mathrm{~m} / \mathrm{year}$, probably reflecting the curved river course (Fig. 12).

Such a rapid coastline migration resulted in a low supply of sediment to coastal and offshore regions; this deduction is supported by incised-valley segments which still form depressions on the modern sea floor (Fig. 3). Furthermore, tidal bars or coastal-parallel barrier systems 
characterizing tide-dominated or wave-dominated estuaries, respectively, did not develop and the river mouth formed an open, funnel-shaped estuary that favoured the incursion of seawater. Thus, the boundary between fluvial lag deposits and estuarine sediments is gradational (Fig. 14). A similar situation characterizes the Pleistocene transgressions in the Celtic Sea Shelf (Reynaud et al., 1999).
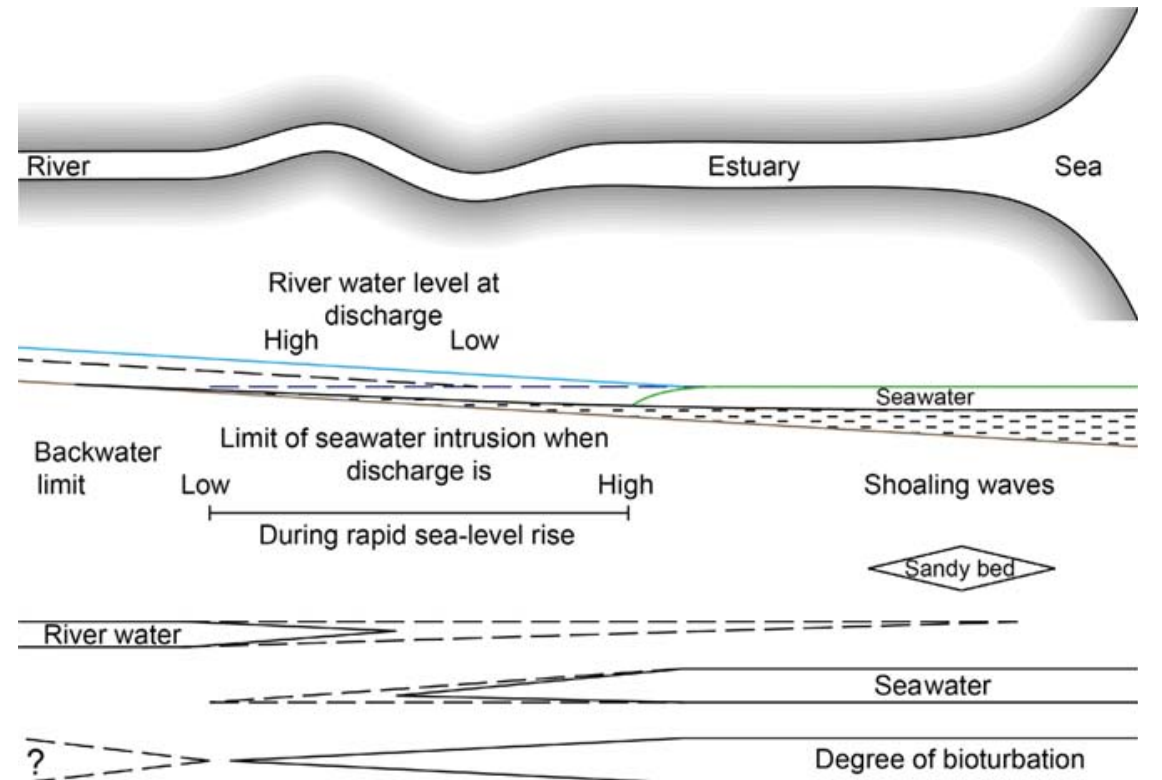

=- $?$ Lamination

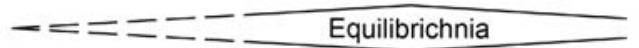

$\begin{array}{llllll}\text { LF1 } & \text { LF2 } & \text { LF2/LF3 } & \text { LF3 } & \text { LF4 } & \text { LF5 }\end{array}$
Fig. 14. Depositional settings, environmental factors, degree of bioturbation, primary sedimentary structures and lithofacies (LF as defined in Fig. 6) in an open funnel-shaped estuarine mouth of an incised valley during rapid Holocene transgression.

The absence of sandy bars and barriers within the mouth area of the ancient Red River during Holocene transgression is supported by observations in the modern delta region. The modern delta evolved around $6 \mathrm{ka}$ from a funnel-shaped estuary (Tanabe et al., 2006). A sandy estuarine system, however, started to form at about $8 \mathrm{ka}$, when the rate of relative sea-level rise began to decelerate, nearly at the same time when the maximum flooding surface (MFS) formed (Tanabe et al., 2006). Similarly, in the mouth region of the Mekong, the MFS is estimated to have formed around $8.2 \mathrm{ka}$ (Nguyen et al., 2010) and at the same time accumulation of coastal barrier sands started (Quang-Minh et al., 2010). Thus, the mouth of the Mekong also appears to have had an open, funnel-shaped estuary with a subordinate development of sand bars. The shelf offshore southern Vietnam is steeper than the Gulf of Tonkin but, nonetheless, sea-level rise was also too rapid to enable a wave-dominated or tidedominated estuary to fully develop. Consequently, the rate of coastline migration has a considerable influence on the development of the river mouth depositional system during transgression. Rapid coastline migration favours the development of open, funnel-shaped estuaries favouring a larger incursion of seawater further upstream compared with the situation in wave-dominated and tide-dominated estuaries. 


\section{CONCLUSIONS}

1 During times of lowered sea-level caused by the last glacial maximum, the ancient Red River and its tributaries incised 10 to $15 \mathrm{~m}$ deep channels in the Gulf of Tonkin. These channels were filled by a facies succession comprising the following (from bottom to top): (i) fluvial lag deposits (up to 0.6 to $0.8 \mathrm{~cm}$ thick); (ii) estuarine mud (up to $9 \mathrm{~m}$ thick); (iii) thin full-marine sand (up to $0.8 \mathrm{~m}$ thick); and (iv) marine mud (up to $4 \mathrm{~m}$ thick). The thin and coarse fluvial sediments suggest that the incised valley persisted in geomorphic disequilibrium because backward incision lagged behind sea-level fall. The erosional potential due to geomorphic disequilibrium became reactivated during sea-level rise when a channel segment shifted into the zone where river discharge and ebb-tidal currents interacted.

2 During the Holocene sea-level rise, the coastline in the Gulf of Tonkin migrated at a rate of 50 to $150 \mathrm{~m} /$ year due to the gentle slope of shelf $(0.2 \mathrm{~m} / \mathrm{km})$. Therefore, during transgression, the river mouth region was undersupplied with sediment and sandy bar or barrier systems, being typical of tide-dominated or wave-dominated estuaries, respectively, did not develop. Instead, the river mouth represented an open, funnel-shaped, mud-dominated estuary. Consequently, besides the two standard endmember models, wave-dominated and tidedominated, an open, funnel-shaped (drowned valley), coastal plain primary estuary needs to be considered for times of rapid sea-level rise. Such a system has not reached depositional equilibrium, and hence can be classified as immature and it seems that the lack of sand may represent an incipient stage of one of the endmembers.

3 The open, funnel-shaped river mouth morphology favoured seawater intrusion further upstream, in particular during periods of low discharge. Consequently, the basal part of the estuarine deposits accumulated in an environment that was stressful for burrowing organisms, as indicated by sparse to absent bioturbational structures. Stress was caused by low or fluctuating salinity, soft sediment consistency and alternating depositional and erosional periods. Run-off varied seasonally particularly during dry seasons when a saltwater wedge is likely to have established. Alternating intervals of laminated and bioturbated mud document recurrent incursion of seawater into the incised-valley system for considerable distances upstream (clearly exceeding $100 \mathrm{~km}$ ).

4 In channel segments having a gentle slope, river flow velocity decelerated and seawater could intrude upstream for longer distances, maybe for several tens to even more than a hundred kilometres. Low flow velocity and saltwater incursion led to fluctuating salinity and enhanced flocculation and deposition of mud. These conditions are stressful for the fauna and result in sparsely bioturbated sediments. Up section the proportion of bioturbated intervals and degree of bioturbation increases.

5 Ichnofabrics and early diagenetic Fe-rich precipitates document a far more dynamic depositional setting than X-ray fluorescence core-scan data or lithology. Mud deposited in a low-salinity to prevailing freshwater setting contains siderite, whereas even short-term seawater incursions favour precipitation of $\mathrm{Fe}$ sulphides. During the estuarine stage, Siphonichnus producers (bivalves) moved several tens of centimetres up or down in the sediment in response to pronounced erosion and rapid deposition of up to $1 \mathrm{~m}$ that is 
otherwise not recorded. The high proportion of vertical burrows counteracts the development of the tiered ichnofabric.

\section{ACKNOWLEDGEMENTS}

The R/V Sonne cruise 220 was funded by the German Ministry of Science and Education (grant no. 03G0220B). B.H. Long (Institute for Oceanography, Nha Trang, Vietnam) and P. Van Phach (Institute for Marine Geology and Geophysics, Hanoi, Vietnam) provided detailed bathymetric information about the Gulf of Tonkin. The Radiology section of the Medical Care Center (Prüner Gang) in Kiel (Germany) generously provided access to their equipment to obtain X-ray radiographs. C. de Capitani (Basel) did the XRD measurements and E. Biehler (Basel) ran the SEM-EDAX analyses. Achim Reisdorf (Basel) drew all of the figures. The initial manuscript could be greatly improved thanks to the constructive comments by $\mathrm{L}$. Buatois (Saskatoon, SK, Canada), S. Dashtgard (Burnaby, BC, Canada), H.D. Johnson (London, UK), A. Simms (Santa Barbara, CA, USA) and an anonymous journal reviewer, and helpful suggestions by the journal's Associate Editor C. Fielding. AW received funds from the Swiss National Foundation (SNF grant no. 200020_140217/1). AS and DU were financially supported by the German Science Foundation (grant no. STA 401-10 to KS). All of these contributions are gratefully acknowledged.

\section{REFERENCES}

Allen, G.P. (1991) Sedimentary processes and facies in the Gironde estuary: a recent model for macrotidal estuarine systems. In: Clastic Tidal Sedimentology - Recognition Criteria and Facies Models (Eds D.G. Smith, B.A. Zaitlin, G.E. Reinson and R.A. Rahmani), Mem. Can. Soc. Petrol. Geol., 16, 29-39.

Alqahtani, F.A., Johnson, H.D., Jackson, C.A.-L. and Som, M.R.B. (2015) Nature, origin and evolution of a Late Pleistocene incised valley-fill, Sunda Shelf Southeast Asia. Sedimentology, $62,1198-1232$.

Arz, H.W., Pätzold, J. and Wefer, G. (1998) Correlated millennial-scale changes in surface hydrography and terrigenous sediment yield inferred from last-glacial marine deposits off Northeastern Brazil. Quatern. Res., 50, 157-166.

Ayranci, K. and Dashtgard, S.E. (2013) Infaunal holothurian distributions and their traces in the Fraser River delta front and prodelta, British Columbia, Canada. Palaeogeogr. Palaeoclimatol. Palaeoecol., 392, 232-246.

Bertling, M., Braddy, S.J., Bromley, R.G., Demathieu, G.R., Genise, J., Mikulas, R., Nielsen, J.K., Nielsen, K.S.S., Rindsberg, A.K., Schlirf, M. and Uchman, A. (2006) Names for trace fossils: a uniform approach. Lethaia, 39, 265-286.

Borges, J. and Huh, Y. (2007) Petrography and chemistry of the bed sediments of the Red River in China and Vietnam: 155-168.

Boyd, R., Dalrymple, R.W. and Zaitlin, B.A. (2006) Estuary and incised valley facies models. In: Facies Models Revisited (Eds H.W. Posamentier and R.G. Walker), SEPM Spec. Publ., 84, 171234. 
Bromley, R.G. (1996) Trace Fossils. Biology, Taphonomy and Applications. Chapman and Hall, London, $361 \mathrm{pp}$.

Bromley, R.G., Asgaard, U. and Jensen, M. (1997) Experimental study of sediment structures created by a spatangoid echinoid, Echinocardium mediterraneum. Proceedings of the Geologists' Association, 108, 183-189.

Buatois, L. and Mángano, G.M. (2011) Ichnology: Organism-Substrate Interactions in Space and Time. Cambridge University Press, Cambridge, 358 pp.

Buatois, L.A., Santiago, N., Parra, K. and Steel, R. (2008) Animal-substrate interactions in an early Miocene wave-dominated tropical delta: delineating environmental stresses and depositional dynamics (Tácata field, eastern Venezuela). J. Sed. Res., 78, 458-479.

Calvert, S.E. and Pedersen, T.F. (2007) Elemental proxies for palaeoclimatic and palaeoceanographic variability in marine sediments: interpretation and application. In: Proxies in Late Cenozoic Paleoceanography (Eds C. Hillaire-Marcel and de Vernal A.), Developments in Marine Geology, $1,567-644$.

Carlin, J.A., Dellapenna, T.M., Strom, K. and Noll, C.J.I. (2015) The influence of a salt wedge intrusion on fluvial suspended sediment and the implications for sediment transport to the adjacent coastal ocean: a study of the lower Brazos River TX, USA. Mar. Geol., 359, 134-147.

Cattaneo, A. and Steel, R.J. (2003) Transgressive deposits: a review of their variability. Earth-Sci. Rev., 62, 187-228.

Curtis, C. (1987) Mineralogical consequences of organic matter degradation in sediments: inorganic/organic diagenesis. In: Marine Clastic Sedimentology (Eds J.K. Leggett and G.G. Zuffa), pp. 108-123. Graham and Trotman, London.

Dalrymple, R.W. (2006) Incised valleys in space and time: an introduction to the volume and an examination of the controls on valley formation and filling. In: Incised Valleys in Space and Time (Eds R.W. Dalrymple, D.A. Leckie and R.W. Tillman), SEPM Spec. Publ., 85, 5-12.

Dalrymple, R.W., Zaitlin, B.A. and Boyd, R. (1992) Estuarine facies models: conceptual basis and stratigraphic implications. J. Sed. Petrol., 62, 1130-1146.

Dalrymple, R.W., Mackay, D.A., Ichaso, A.A. and Choi, K.S. (2012) Processes, morphodynamics, and facies of tide-dominated estuaries. In: Principles of Tidal Sedimentology (Eds. R.A. Davis Jr and R.W. Dalrymple), pp. 79-107. Springer, Dordrecht, Heidelberg.

Dashtgard, S.E., Venditti, J.G., Hill, P.R., Sisulak, C.F., Johnson, S.M. and La Croix, A.D. (2012) Sedimentation across the tidal-fluvial transition in the lower Fraser River, Canada. Sedimentary Record, 10, 4-9.

Davis, R.A. Jr and Fitzgerald, D.M. (2004) Beaches and Coasts. Blackwell, Oxford, 419 pp.

Díez-Canseco, D., Buatois, L.A., Mángano, M.G., Rodriguez, W. and Solorzano, E. (2016) The ichnology of the fluvial-tidal transition: interplay of ecologic and evolutionary controls. In: Fluvial-Tidal Sedimentology (Eds P. Ashworth, J. Best and D.R. Parsons), Dev. Sedimentol., 68, 283-321.

Duc, D.M., Nhuan, M.T., Ngoi, C.V., Nghi, T., Tien, D.M., van Weering, T.C.E. and van den Bergh, G.D. (2007) Sediment distribution and transport at the nearshore zone of the Red River delta, Northern Vietnam. J. Asian Earth Sci., 29, 558-565.

Duc, D.M., Thanh, D.X., Quynh, D.T. and McLaren, P. (2016) Analysis of sediment distribution and transport for mitigation of sand deposition hazard in Tam Quan estuary, Vietnam. Environmental Earth Sciences, 75, 1-13. 
Fagherazzi, S., Howard, A.D. and Wiberg, P.L. (2004) Modeling fluvial erosion and deposition on continental shelves during sea level cycles. J. Geophys. Res., 109, 1-16.

Fouch, T.D. and Dean, W.E. (1982) Lacustrine and associated clastic depositional environments. In: Sandstone Depositional Environments (Eds P.A. Scholle and D. Spearing), AAPG Mem., 31, 87114.

Fyhn, M.B.W. and Phach, P.V. (2014) Late Neogene structural inversion around the northern Gulf of Tonkin, Vietnam: effects of right-lateral displacement across the Red River fault zone. Tectonics, $33,290-312$.

Gerard, J. and Bromley, R. (2008) Ichnofabrics in Clastic Sediments. Jean R.F. Gerard, Madrid, 100 pp.

Gingras, M.K., MacEachern, J.A., Dashtgard, S.E., Zonneveld, J.-P., Schoengut, J., Ranger, M.J. and Pemberton, S.G. (2012) Estuaries. In: Trace Fossils as Indicators of Sedimentary Environments (Eds D. Knaust and R.G. Bromley), Dev. Sedimentol., 64, 463-505. Elsevier, Amsterdam.

Gong, Z.S., Huang, L.F. and Chen, P.H. (2011) Neotectonic controls on petroleum accumulations, offshore China. J. Petroleum Geol., 34, 5-28.

Hanebuth, T.J.J. and Stattegger, K. (2003) The stratigraphic evolution of the Sunda Shelf during the past fifty thousand years. In: Tropical Deltas of Southeast Asia - Sedimentology, Stratigraphy, and Petroleum Geology (Eds F.H. Sidi, D. Nummedal, P. Imbert, H. Darman and H.W. Posamentier), SEPM Spec. Publ., 76, 189-200.

Hanebuth, T., Stattegger, K. and Grootes, P.M. (2000) Rapid flooding of the Sunda Shelf: a late glacial sea-level record. Science, 288, 1033-1035.

Hanebuth, T.J.J., Stattegger, K. and Bojanowski, A. (2009) Termination of the Last Glacial Maximum sea-level lowstand: the Sunda-Shelf data revisited. Global Planet. Change, 66, 76-84.

Hanebuth, T.J.J., Voris, H.K., Yokoyama, Y., Saito, Y. and Okuno, J. (2011) Formation and fate of sedimentary depocentres on Southeast Asia's Shelf over the past sea-level cycle and biogeographic implications. Earth-Sci. Rev., 104, 92-110.

Hanken, N.-M., Bromley, R.G. and Thomsen, E. (2001) Trace fossils of the bivalve Panopea faujasi, Pliocene, Rhodes, Greece. Ichnos, 8, 117-130.

Häntzschel, W. (1975) Trace Fossils and Problematica. Geological Society of America and University of Kansas, New York and Lawrence, 269 pp.

Haruyama, S. (1995) Geomorphic environment of Tonkin delta. The Study of International Relations, Tsuda College, 21, 1-13 (in Japanese).

HELCOM (2012) Checklist of Baltic Sea Macro-species. Baltic Sea Environment Proceedings, 130, 203. HELCOM, Helsinki.

Hertweck, G. (1972) Distribution and environmental significance of lebensspuren and in situ skeletal remains. Senckenb. Marit, 4, 125-167.

Hori, K., Tanabe, S., Saito, Y., Haruyama, S., Nguyen, V. and Kitamura, A. (2004) Delta initiation and Holocene sea-level change: example from the Song Hong (Red River) delta, Vietnam. Sed. Geol., 164, 237-249.

Johnson, S.M. and Dashtgard, S.E. (2014) Inclined heterolithic stratification in a mixed-tidal-fluvial channel: differentiating tidal versus fluvial controls on sedimentation. Sed. Geol., 301, 41-53. 
Kasten, S., Freudenthal, T., Gingele, F.X. and Schulz, H.D. (1998) Simultaneous formation of ironrich layers at different redox boundaries in sediments of the Amazon deep-sea fan. Geochim. Cosmochim. Acta, 62, 2253-2264.

Kędzierski, M., Uchman, A., Sawlowicz, Z. and Briguglio, A. (2014) Fossilized bioelectric wire - the trace fossil Trichichnus. Biogeosci., 12, 2301-2309.

Knaust, D. (2012) Trace fossil systematics. In: Trace Fossils as Indicators of Sedimentary Environments (Eds D. Knaust and R.G. Bromley), Dev. Sedimentol., 64, 79-101. Elsevier, Amsterdam.

Knaust, D. (2015) Siphonichnidae (new ichnofamily) attributed to the burrowing activity of bivalves: ichnotaxonomy, behaviour and palaeoenvironmental implications. Earth-Sci. Rev., 150, 497-519.

Knox, G.A. (1986) Estuarine Ecosystems: A Systems Approach (Volume I). CRC Press, Boca Raton, $289 \mathrm{pp}$.

Kostaschuk, R.A., Church, M.A. and Luternbauer, J.L. (1992) Sediment transport over salt-wedge intrusions: Fraser River estuary, Canada. Sedimentology, 39, 305-317.

La Croix, A.D. and Dashtgard, S.E. (2014) Of sand and mud: sedimentological criteria for identifying the turbidity maximum zone in a tidally influenced river. Sedimentology, 62, 1961-1981.

Lalli, C.M. and Parsons, T.R. (1993) Biological Oceanography. Pergamon, Oxford, New York, 301 pp.

Lettley, C.D., Pemberton, S.G., Gingras, M.K., Ranger, M.J. and Blakney, B.J. (2009) Integrating sedimentology and ichnology to shed light on the system dynamics and paleogeography of an ancient riverine estuary. In: Applied Ichnology (Revised Edition) (Eds J.A. MacEachern, K.L. Bann, M.K. Gingras and S.G. Pemberton), SEPM Short Course Notes, 52, 147-165.

Liu, Z.F., Zhao, Y.L., Ri, J.R. and Colin, C. (2007) Late Quaternary clay minerals off Middle Vietnam in the western South China Sea: implications for source analysis and East Asian monsoon evolution. Sci. China, Ser. D Earth Sci., 50, 1674-1684.

Loget, N. and Van Den Driessche, J. (2009) Wave train model for knickpoint migration. Geomorphology, 106, 376-382.

Löwemark, L. (2003) Automatic image analysis of X-ray radiographs: a new method for ichnofabric evaluation. Deep-Sea Research I, 50, 815-827.

MacEachern, J., Pemberton, S.G., Bann, K.L. and Gingras, M.K. (2009) Departures from the archetypical ichnofacies: effective recognition of physico-chemical stresses in the rock record. In: Applied Ichnology (Revised Edition) (Eds J.A. MacEachern, K.L. Bann, M.K. Gingras and S.G. Pemberton), SEPM Short Course Notes, 52, 65-93.

Mathers, S. and Zalasiewicz, J. (1999) Holocene sedimentary architecture of the Red River Delta, Vietnam. J. Coastal Res., 15, 314-325.

Mattheus, C.R. and Rodriguez, A.B. (2011) Controls on late Quaternary incised-valley dimension along passive margins evaluated using empirical data. Sedimentology, 58, 1113-1137.

Meade, R.H. (1969) Landward transport of bottom sediments in estuaries of the Atlantic coastal plain. J. Sed. Petrol., 39, 222-234.

Mitchell, A.H.G. and Reading, H.G. (1986) Sedimentation and tectonics. In: Sedimentary Environments and Facies (Ed. H.G. Reading), ${ }^{\text {nd }}$ edn, pp. 471-519. Blackwell, Oxford. 
Monaco, P. (2014) Taphonomic aspects of the radial backfill of Asterosomids in Oligo-Miocene turbidites of central Italy (northern Apennines). Rivista Italiana di Paleontología e Stratigrafia, $120,215-224$.

Nadeau, M.J., Schleicher, M., Grootes, P.M., Erlenkeuser, H., Gottdang, A., Mous, D.J.W., Sarnthein, J.M. and Willkomm, H. (1997) The Leibniz-Labor AMS facility at the Christian-Albrechts University, Kiel, Germany. Nucl. Instrum. Methods Phys. Res., Sect. B, 123, 22-30.

Nadeau, M.J., Grootes, P.M., Schleicher, M., Hasselberg, P., Rieck, A. and Bitterling, M. (1998) Sample throughput and data quality at the Leibniz-Labor AMS facility. Radiocarbon, 40, 239245.

Nguyen, V.L., Ta, T.K.O. and Saito, Y. (2010) Early Holocene initiation of the Mekong River delta, Vietnam, and the response to Holocene sea-level changes detected from DT1 core analyses. Sed. Geol., 230, 146-155.

Ni, Y., Harff, J., Xia, Z., Waniek, J.J., Endler, M. and Schulz-Bull, D.E. (2016) Post-glacial mud depocentre in the southern Beibu Gulf: acoustic features and sedimentary environment evolution. In: River-Dominated Shelf Sediments of East Asian Seas (Eds P.D. Clift, J. Harff, J. Wu and Q. Yan), Geological Society Special Publication, 429, 87-98.

Niino, H. and Emery, K.O. (1961) Sediments of shallow portions of East China Sea and South China Sea. Geol. Soc. Am. Bull., 72, 731-762.

Peltier, W.R. and Fairbanks, R.G. (2006) Global glacial ice volume and Last Glacial Maximum duration from an extended Barbados sea level record. Quatern. Sci. Rev., 25, 3322-3337.

Pemberton, S.G.E. (1992) Applications of Ichnology to Petroleum Exploration. SEPM Core Workshop, Course Notes, 17, 429 pp.

Pemberton, S.G. and Frey, R.W. (1982) Trace fossil nomenclature and the Planolites-Palaeophycus dilemma. J. Paleontol., 56, 843-881.

Pemberton, S.G. and Frey, R.W. (1985) The Glossifungites ichnofacies: modern examples from the Georgia coast. In: Biogenic Sedimentary Structures: Their Use in Interpreting Depositional Environments (Ed. H.A. Curran), SEPM Spec. Publ., 35, 237-304.

Pemberton, S.G., Reinson, G.E. and MacEachern, J.A. (1992) Comparative ichnological analysis of late Albian estuarine valley-fill and shelf-shoreface deposits, Crystal Viking Field, Alberta. In: Applications of Ichnology to Petroleum Exploration (Ed. S.G. Pemberton), SEPM Core Workshop, Course Notes, 17, 291-317.

Pemberton, S.G., Spila, M., Pulham, A.J., Saunders, T., MacEachern, J.A., Robbins, D. and Sinclair, I.K. (2001) Ichnology and Sedimentology of Shallow to Marginal Marine Systems. Geological Association of Canada, Short Course Notes, 15, 343 pp.

Pemberton, S.G., Gingras, M.K., Dashtgard, S.E., Bann, K.L. and MacEachern, J.A. (2010) The Teichichnus Ichnofacies: a recurring ethological grouping for salinity-stressed ichnological suites. $18^{\text {th }}$ International Sedimentological Congress, Mendoza (Argentina), Abstracts, 684.

Perillo, G.M.E. (1995) Definitions and geomorphologic classifications of estuaries. In: Geomorphology and Sedimentology of Estuaries (Ed. G.M.E. Perillo), Dev. Sedimentol., 53, $17-$ 47.

Poggioli, A.R. and Horner-Devine, A.R. (2015) The sensitivity of salt wedge estuaries to channel geometry. J. Phys. Oceanogr., 45, 3169-3183.

Portela, L.I., Ramos, S. and Teixeira, A.T. (2013) Effects of salinity on the settling velocity of fine sediments of a harbour basin. J. Coastal Res., 65, 1188-1193. 
Postma, D. (1982) Pyrite and siderite formation in brackish and freshwater swamp sediments. Am. J. Sci., 282, 1151-1183.

Quang-Minh, D., Frechen, M., Nghi, T. and Harff, J. (2010) Timing of Holocene sand accumulation along the coast of central and SE Vietnam. Int. J. Earth Sci., 99, 1731-1740.

Reimer, P.J., Baillie, M.G.L., Bard, E., Bayliss, A., Beck, J.W., Blackwell, P.G., Bronk Ramsey, C., Buck, C.E., Burr, G.S., Edwards, R.L., Friedrich, M., Grootes, P.M., Guilderson, T.P., Hajdas, I., Heaton, T.J., Hogg, A.G., Hughen, K.A., Kaiser, K.F., Kromer, B., McCormac, F.G., Manning, S.W., Reimer, R.W., Richards, D.A., Southon, J.R., Talamo, S., Turney, C.S.M., van der Plicht, J. and Weyhenmeyer, C.E. (2009) IntCal09 and Marine09 radiocarbon age calibration curves, 050,000 years cal BP. Radiocarbon, 51, 1111-1150.

Remane, A. (1934) Die Brackwasserfauna. Zoologischer Anzeiger, 7. Supplementband (Verhandlungen der Deutschen Zoologischen Gesellschaft auf der 36. Jahresversammlung), 3474.

Reynaud, J.-Y., Tessier, B., Proust, J.-N., Dalrymple, R., Bourillet, J.-F., de Batist, M., Lericolais, G., Berné, S. And Marsset, T. (1999) Architecture and sequence stratigraphy of a late Neogene incised valley at the shelf margin, southern Celtic Sea. J. Sed. Res., 69, 351-364.

Richter, T.O., der van Gaast, S., Koster, B., Vaars, A., Gieles, R., de Stigter, H.C., de Haas, H. and van Weering, T.C.E. (2006) The avaatech core scanner: technical description and applications to NE Atlantic sediments. In: New Ways of Looking at Sediment Core and Core Data (Ed. R.G. Rothwell), Geological Society Special Publication, 267, 39-50.

Rickard, D. and Luther, G.W.I. (2007) Chemistry of iron sulfides. Chem. Rev., 107, 514-562.

Ricketts, E.F., Calvin, J. and Hedgepeth, J.W. (1985) Between Pacific Tides ( $5^{\text {th }}$ Edition, Revised by D.W. Philips). Stanford University Press, Stanford, 652 pp.

Schäfer,W. (1956) Wirkungen der Benthos-Organismen auf den jungen Schichtverband. Senckenb. Lethaea, 37, 183-263.

Schimanski, A. and Stattegger, K. (2005) Deglacial and Holocene evolution of the Vietnam shelf: stratigraphy, sediments and sea-level change. Mar. Geol., 214, 365-387.

Schubel, J.R. and Meade, R.H. (1977) Man's impact on estuarine sedimentation. Estuarine Pollution Control and Assessment - Proceedings of a Conference I, pp. 193-209. U.S. Government Printing Office, Washington.

Schumm, S.A. (1993) River response to base level change: implications for sequence stratigraphy. J. Geol., 101, 279-294.

Simms, A.R., Anderson, J.B., Taha, Z.P. and Rodriguez, A.B. (2006) Overfilled versus underfilled incised valleys: examples from the Quaternary Gulf of Mexico. In: Incised Valleys in Space and Time (Eds R.W. Dalrymple, D.A. Leckie and R.W. Tillman), SEPM Spec. Publ., 85, 117-139.

Smilek, K.R. and Hembree, D.I. (2012) Neoichnology of Thyonella gemmata: a case study for understanding holothurian ichnofossils. Open Paleontol. J., 4, 1-10.

Stattegger, K., Tjallingii, R., Saito, Y., Michelli, M., Trung Thanh, N. and Wetzel, A. (2013) Mid- to late Holocene sea-level reconstruction of Southeast Vietnam using beachrock and beach-ridge deposits. Global Planet. Change, 110, 214-222.

Stuiver, M. and Polach, H.A. (1977) Discussion: reporting of ${ }^{14} \mathrm{C}$ data. Radiocarbon, 19, 355-363.

Sutherland, B.R., Barrett, K.J. and Gingras, M.K. (2015) Clay settling in fresh and salt water. Environ. Fluid Mech., 15, 147-160. 
Szczuciński, W., Jagodziński, R., Hanebuth, T.J.J., Stattegger, K., Wetzel, A., Mitręga, M., Unverricht, D. and Van Phach, P. (2013) Modern sedimentation and sediment dispersal pattern on the continental shelf off the Mekong River delta, South China Sea. Global Planet. Change, 110, $195-213$.

Tanabe, S., Hori, K., Saito, Y., Haruyama, S., Vu, P.V. and Kitamura, A. (2003) Song Hong (Red River) delta evolution related to millennium-scale Holocene sea-level changes. Quatern. Sci. Rev., 22, 2345-2361.

Tanabe, S., Saito, Y., Vu, Q.L., Hanebuth, T.J.J., Ngo, Q.L. and Kitamura, A. (2006) Holocene evolution of the Song Hong (Red River) delta system, northern Vietnam. Sed. Geol., 187, 29-61.

Tanabe, S., Nakanishi, T., Ishihara, Y. and Nakashima, R. (2015) Millennial-scale stratigraphy of a tide-dominated incised valley during the last $14 \mathrm{kyr}$ : spatial and quantitative reconstruction in the Tokyo Lowland, central Japan. Sedimentology, 62, 1837-1872.

Tjallingii, R. (2007) Application and quality of XRF core scanning in reconstructing late Pleistocene NW African continental margin sedimentation and paleoclimate variations. $\mathrm{PhD}$ Thesis, Universität Bremen, $114 \mathrm{pp}$.

Tjallingii, R., Stattegger, K., Wetzel, A. and Van Pach, P. (2010) Infilling and flooding of the Mekong River incised valley system during deglacial sea-level rise. Quatern. Sci. Rev., 29, 1432-1444.

Tjallingii, R., Stattegger, K., Stocchi, P., Saito, Y. and Wetzel, A. (2014) Rapid flooding of the southern Vietnam shelf during the early to mid-Holocene. J. Quat. Sci., 29, 581-588.

Tomczak, M. and Godfrey, J.S. (1994) Regional Oceanography. Pergamon, London, 422 pp.

Uchman, A., Bubniak, I. and Bubniak, A. (2000) The Glossifungites ichnofacies in the area of its nomenclatural archetype, Lviv, Ukraine. Ichnos, 7, 183-193.

van Maren, D.S. (2007) Water and sediment dynamics in the Red River mouth and adjacent coastal zone. J. Asian Earth Sci., 29, 508-522.

Voris, H.K. (2000) Maps of Pleistocene sea levels in Southeast Asia: shorelines, river systems and time durations. J. Biogeogr., 27, 1153-1167.

Wang, P. and Li, Q. (2009) The South China Sea. Paleoceanography and Sedimentology. Springer, Berlin, Heidelberg, New York, 506 pp.

Wang, L., Sarnthein, M., Erlenkeuser, H., Grimalt, J., Grootes, P., Heilig, S., Ivanova, E., Kienast, M., Pelejero, C. and Pflaumann, U. (1999) East Asian monsoon climate during the Late Pleistocene: high-resolution sediment records from the South China Sea. Mar. Geol., 156, 245-284.

Weltje, G.J. and Tjallingii, R. (2008) Calibration of XRF core scanners for quantitative geochemical logging of sediment cores: theory and application. Earth Planet. Sci. Lett., 274, 423-438.

Werner, F. (1967) Röntgen-Radiographie zur Untersuchung von Sedimentstrukturen. Umschau, 16, 532.

Werner, F. (2002) Bioturbation structures in marine Holocene sediments of Kiel Bay (Western Baltic). Meyniana, 54, 41-72.

Wetzel, A. (1981) Ökologische und stratigraphische Bedeutung biogener Gefüge in quartären Sedimenten am NW-afrikanischen Kontinentalrand. "Meteor" Forschungs-Ergebnisse, Reihe C, $34,1-47$.

Wetzel, A. (2010) Deep-sea ichnology: observations in modern sediments to interpret fossil counterparts. Acta Geol. Pol., 60, 125-138. 
Wetzel, A. and Bromley, R.G. (1994) Phycosiphon incertum revisited: Anconichnus horizontalis is its junior subjective synonym. J. Paleontol., 68, 1396-1402.

Wetzel, A., Williams, C., Kassens, H., Leger, G. and Auroux, C. (1990) Comparison between laboratory-determined physical properties and downhole measurements in outer Bengal Fan deposits. In: Proceedings of the Ocean Drilling Program, Scientific Results (Eds J.R. Cochran, D.A.V. Stow, C. Aroux, K. Amano, P.S. Balson, J. Boulègue, G. Brass, S. Gartner, S. Hall, S. Iaccarino, T. Ishizuka, I. Kaczmarska, H. Kassens, C. Leger, F. Proto Decima, V.C. Raman, W. Sager, K. Takahashi, T. Thompson, J.-J. Tiercelin, M. Townsend, N.P. Wijayananda, A. Wetzel and C. Williams), 116, 69-74. Ocean Drilling Program, College Station, TX.

Wiesner, M.G., Stattegger, K., Pohlmann, T., Chen, F., Heddaeus, A., Heyckendorff, K., Jechlitschek, H., Lahajnar, N., Liskow, I., Li, X., Liu, Z., Lorenc, S., Metzke, M., M€uller, M., Peleo-Alampay, A., Schönke, M., Schwarzer, K., Szczygielski, A., Steen, E., Unverricht, D., Wang, X., Welsch, A., Wetzel, A. And Zhao, Y. (2012) Cruise Report RV Sonne 220 - Land-Ocean-Atmosphere Interactions in the Gulf of Tonkin. Institut für Geowissenschaften Universität Kiel, 101 pp.

Winn, K. (2006) Bioturbation structures in marine Holocene sediments of the Great Belt (Western Baltic). Meyniana, 58, 157-178.

Zaitlin, B.A., Dalrymple, R.W. and Boyd, R. (1994) The stratigraphic organization of incised-valley systems associated with relative sea-level change. In: Incised-Valley Systems: Origin and Sedimentary Sequences (Eds R.W. Dalrymple, B.A. Zaitlin and P.A. Scholle), SEPM Spec. Publ., $51,45-60$.

Zhang, G., Uchman, A., Chodyn, R. and Bromley, R.G. (2008) Trace fossil Artichnus pholeoides igen. nov. isp. nov. in Eocene turbidites, Polish Carpathians: possible ascription to holothurians. Acta Geol. Pol., 58, 75-86.

Zhang, X., Lin, C.-M., Dalrymple, R.W., Gao, S. and Li, Y.-L. (2014) Facies architecture and depositional model of a macrotidal incised-valley succession (Qiantang River estuary, eastern China), and differences from other macrotidal systems. Geol. Soc. Am. Bull., 126, 499-522.

Zonneveld, J.-P. and Gingras, M.K. (2013) The ichnotaxonomy of vertically oriented, bivalvegenerated equilibrichnia. J. Paleoclimatol., 87, 243-253. 
APPENDIX A Photographs (CP) and X-ray radiographs (XR) of studied cores

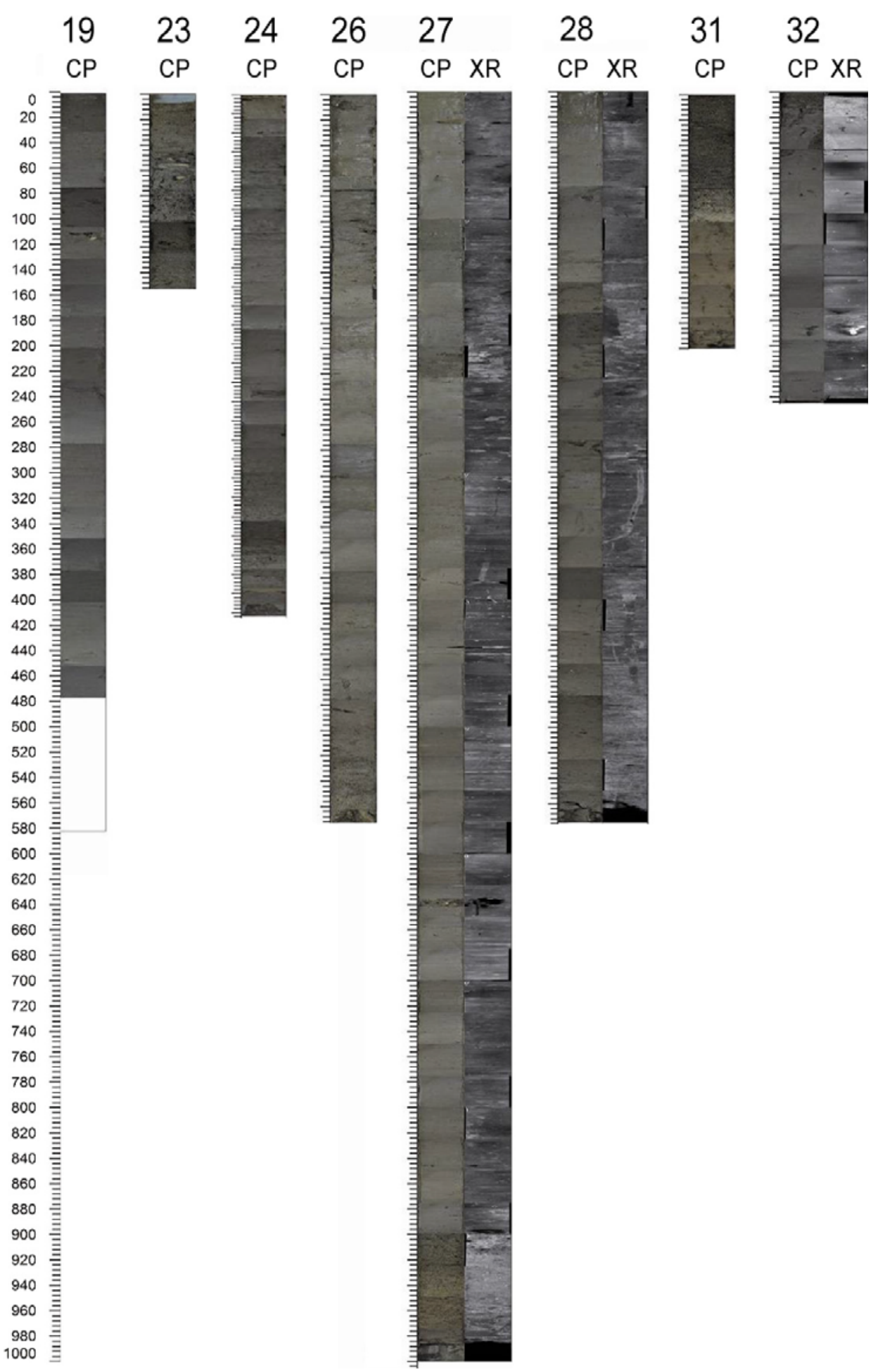




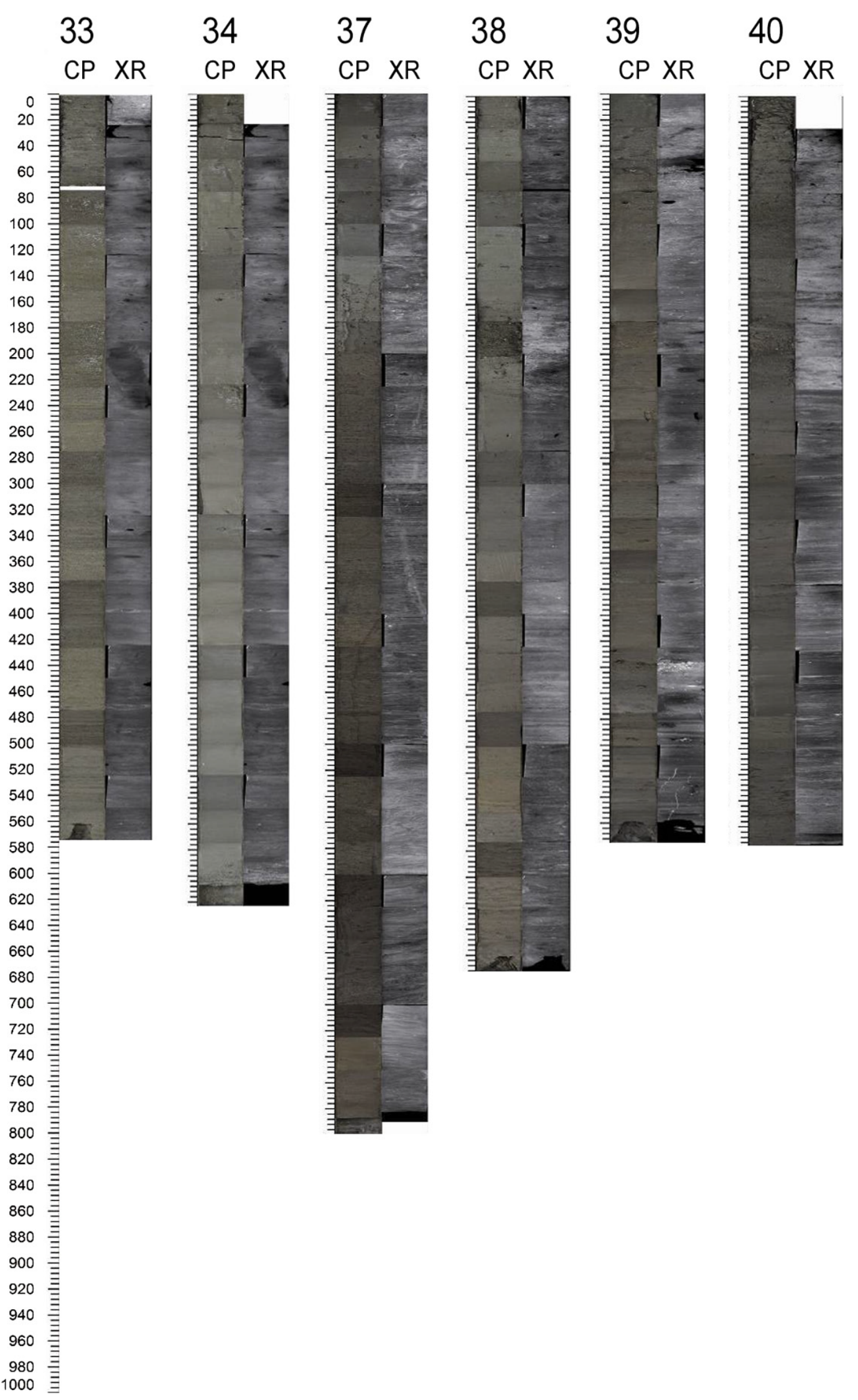




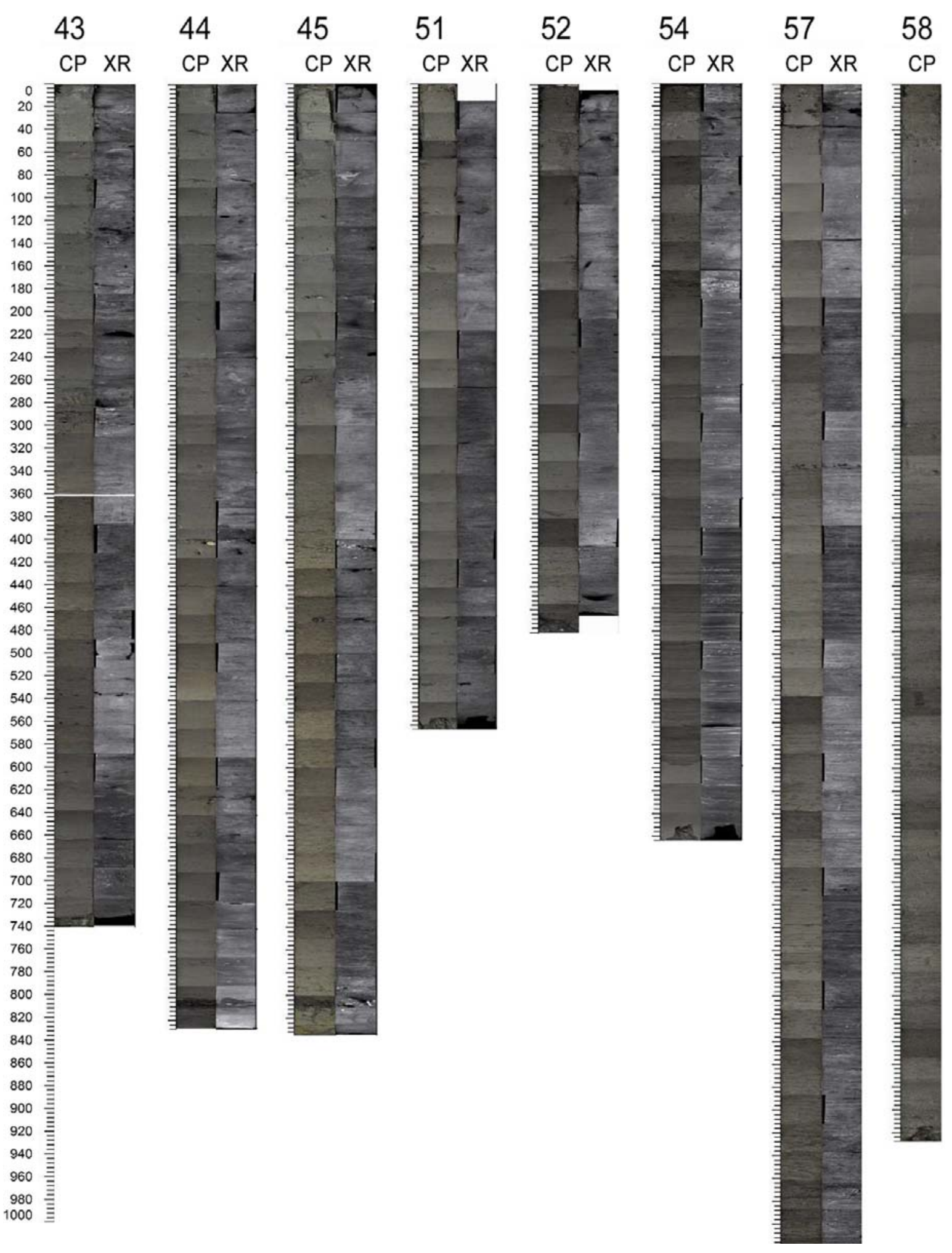

